\title{
Distribution and ecology of planktic foraminifera in the North Pacific:
}

Implications for paleo-reconstructions

Ben J Taylor ${ }^{1}$, James W B Rae ${ }^{1}$, William R Gray ${ }^{1}$, Kate F Darling ${ }^{2,3}$, Andrea Burke ${ }^{1}$ Rainer Gersonde ${ }^{4}$, Andrea Abelmann ${ }^{4}$, Edith Maier ${ }^{4}$, Oliver Esper ${ }^{4}$, Patrizia Ziveri ${ }^{5,6}$

${ }^{1}$ School of Earth and Environmental Sciences, University of St Andrews, UK

${ }^{2}$ School of Geography and Sustainable Development, University of St Andrews, UK

${ }^{3}$ School of Geosciences, University of Edinburgh, UK

${ }^{4}$ Alfred Wegener Institute, Helmholtz Centre for Polar and Marine Research, Bremerhaven, Germany

${ }^{5}$ Institute of Environmental Science and Technology (ICTA), Universitat Autònoma Barcelona (UAB), Bellaterra 08193, Spain

${ }^{6}$ Catalan Institution for Research and Advanced Studies (ICREA), Pg. Lluís Companys 23, Barcelona 08010, Spain

Corresponding author: bjt@st-andrew.ac.uk

\section{Highlights}

- G. bulloides and N. pachyderma are mainly found in the top $50 \mathrm{~m}$.

- Food availability is the main driver of abundance in G. bulloides.

- Temperature is the dominant control on N. pachyderma abundance.

- Dissolution may bias assemblage records towards resistant planktic foraminifera. 


\section{Abstract}

Planktic foraminifera census data have been used to reconstruct past temperatures through transfer functions, as well as changes in ocean ecosystems, chemistry and circulation. Here we present new multinet and core-top census data from 15 sites in the Subpolar North Pacific. We combine these with previous data to provide an up to date compilation of North Pacific planktic foraminifera assemblage data. Our compilation is used to define 6 faunal zones: the subpolar zone; transitional zone; upwelling zone; subtropical zone; east equatorial zone; west equatorial zone; based on the distribution of 10 major species of planktic foraminifera. Two species of planktic foraminifera Neogloboquadrina pachyderma and Globigerina bulloides provide the basis for many subpolar paleo-reconstructions. Through the analysis of new multinet and CTD data we find that G. bulloides and N. pachyderma are predominantly found within 0-50 m of the water column and coincide with high food availability. $N$. pachyderma also shows a strong temperature control and can thrive in food poor waters where temperatures are low. Both species bloom seasonally, particularly during the spring bloom of March to June, with $G$. bulloides exhibiting greater seasonal variation. We suggest that percentage abundance of $N$. pachyderma in paleo-assemblages can be used to assess relative changes in past temperature, with $G$. bulloides abundance more likely to reflect changes in food availability. By comparing our core-top and multinet data, we also find a dissolution bias of $G$. bulloides over $N$. pachyderma in the North Pacific, which may enrich assemblages in the latter species.

\section{Introduction}

Planktic foraminifera provide a key tool in studies of past changes in climate. Foraminiferal species assemblages may track a variety of oceanographic conditions, including temperature, salinity and nutrients, while the geochemistry of foraminiferal calcite can be used to reconstruct quantitative changes in ocean temperature and chemistry through time. However, downcore studies using foraminifera can only be justified if modern calibrations are well established, giving context to paleorecords. The upper water column may vary vertically, seasonally and spatially across the global ocean and it is therefore of prime importance that modern assemblages are fully understood in order to disentangle downcore signals.

Planktic foraminifera are known to exhibit variable depth distribution and seasonal abundance, thus identifying constraints on these variables has become vital to the interpretation of paleo-data (Schiebel and Hemleben, 2017). Early work using plankton tows and isotopic data suggested that planktic foraminifera are most abundant at chlorophyll maxima and that species were vertically stratified in accordance with their temperature preferences (Fairbanks and Wiebe, 1980; Fairbanks et al. 1982; Hemleben et al. 1989). The vertical distribution of planktic foraminifera in the North Pacific 
and globally has been linked to phytoplankton productivity and food availability which are in turn related to variations in the pycnocline and thermocline. In the North-West Pacific, recent literature highlights the role of nutrients and seasonal changes in the thermocline as key drivers of foraminiferal abundance (Mohiuddin et al. 2002; Kuroyanagi et al. 2002; Eguchi et al. 2003; Mohiuddin et al. 2004; Mohiuddin et al. 2005; Kuroyanagi et al. 2008). Despite this, large regional variations in depth preference and abundance have been observed within individual species, suggesting that there are regional discrepancies in the North Pacific assemblages which are not accounted for in paleo-records (Kuroyanagi et al. 2002; Field, 2004; Iwasaki et al. 2017). Three key species of planktic foraminifera dominate high-latitude assemblages in the North Pacific, Neogloboquadrina pachyderma, Globigerina bulloides and Turborotalita quinqueloba. Note that here and throughout, we refer to N. pachyderma sinistral as N. pachyderma, and previous references to N. pachyderma dextral as Neogloboquadrina incompta (Darling et al, 2006). T. quinqueloba is ubiquitous throughout subpolar and polar waters but is often under-represented in assemblage counts, due to its small size (Kandiano and Bauch, 2002). For this reason, it is rarely used in paleoceanographic reconstructions, unless a size fraction of $>125$ $\mu \mathrm{m}$ is used. Seasonally resolved data from the North East Pacific records the apparent affinity of specific species, particularly G. bulloides, to the spring upwelling conditions off the coast of southern California and Vancouver (Sautter and Thunell, 1989; Thunell and Sautter, 1991), which is accompanied by high phytoplankton abundance (Thunell and Honjo, 1987). In contrast, Davis et al. (2016) demonstrate the upwelling affinity of N. pachyderma over G. bulloides in the California coastal upwelling further to the north. Such contrasting differences between adjacent regional assemblages imposes complexity, which can be used to further refine paleoceanographic reconstructions.

Although detailed compilations of planktic foraminifera assemblages are available globally, the North Pacific is poorly represented (Rutherford et al. 1999; Fenton et al. 2016, Siccha and Kucera, 2017). The North Pacific has abyssal depths of $>5500 \mathrm{~m}$, resulting in poor preservation of foraminiferal calcite (Peterson, 1966; Berger, 1970). The lack of preservation, particularly in core-top material, has meant that the distribution and paleoecological significance of planktic foraminifera in the North Pacific is poorly constrained. The difficulty of constraining dissolution effects on sediment also impacts upon the use of North Pacific census data in downcore records (Berger, 1970). North Pacific planktic foraminiferal provinces, or faunal zones, were originally characterised by Bradshaw (1959) and further constrained by Coulbourn et al. (1980). The zones: subarctic; transitional; central and equatorial were defined broadly by the relative abundance of $N$. pachyderma, T. quinqueloba, G. bulloides, Globorotalia inflata and Globigerinoides ruber in core-top samples (Coulbourn et al. 1980).

In this study, we generate new planktic foraminifera assemblage data from plankton tows and core tops collected from 15 sites across the subpolar North Pacific. We combine these data with previously 
published planktic foraminifera core top, multinet and sediment trap assemblage data from the North Pacific, to characterise the ocean conditions associated with modern planktic foraminifera assemblages. This evidence is then used to constrain the depth habitat of individual subpolar species, for the better understanding of paleo-records. To do so, we first address the gap in North Pacific census data, particularly prevalent in the subpolar gyre (Rutherford et al. 1999), by re-evaluating North Pacific planktic foraminifera faunal provinces using our new data compilation. We then focus in detail on the two key subpolar North Pacific proxy carriers, G. bulloides and N. pachyderma. Through assessment of their dominant ecological drivers in the surface ocean, we suggest how best to interpret both the assemblage and geochemical records of these species downcore. Surface water and sediment assemblages are then compared, highlighting the effects of both seasonality and dissolution as potential biases within the sediment record.

\section{Oceanographic Setting}

Oceanographic currents in the North Pacific are dominated by two large-scale gyres: the subpolar gyre and the subtropical gyre, separated by the Subarctic Front, which is marked by a pronounced latitudinal sea surface temperature gradient (Figure 1). This gradient is also seen within salinity and nutrient records, with the subpolar gyre exhibiting higher nutrients and low salinity, whilst the subtropical gyre is comparatively saltier and nutrient poor (Locarnini et al.2013; Zweng et al. 2013; Garcia et al. 2014).

The subpolar gyre can be further split into the West Pacific Gyre and the Alaskan Gyre (Harrison et al. 2004). The West Pacific Gyre is a high nutrient low chlorophyll zone (HNLC) which is fed predominantly by cool, nutrient rich waters from the Sea of Okhotsk and the Kamchatka Current (Locarnini et al.2013; Garcia et al. 2014). The southern extent of this gyre is the Subarctic Current, a region along the Subarctic Front characterised by the confluence of a number of current systems (Figure 1). These include the warm Kuroshio Current originating from the subtropical gyre, the cold Oyashio Current originating from the West Pacific Gyre together with a number of minor currents (Yasuda, 2003; Figure 1). The Subarctic Current and Kuroshio Extension define, in part, the Subarctic Front (Figure 1) which roughly follows $40^{\circ} \mathrm{N}$ latitude zonally across the North Pacific. In the eastern North Pacific, the California Current splits towards the south in the Subtropical Gyre, whilst the Alaskan Current forms the eastern limb of the Alaskan Gyre (Figure 1). The Alaskan gyre, also a HNLC zone, is more nutrient limited than the West Pacific gyre (Harrison et al. 2004) and thus productivity is reduced. It feeds the Bering Sea which consists primarily of the Bering Slope current in the east and the Kamchatka current to the west (Figure 1) (Stabeno and Reed, 1994). In the Subtropical Gyre, the California Current extends southward to the equator where it forms the North Pacific Equatorial Current. In the east 
Equatorial Pacific, the North Pacific Equatorial Current is characterised by upwelling of cooler nutrient rich waters (Locarnini et al.2013; Zweng et al. 2013; Garcia et al. 2014), contributing to the formation of the east equatorial upwelling region where productivity is high (Wyrtki, 1981). The current continues along the equator to the west, where it enters the West Pacific warm pool (Yan et al. 1992) and continues to form the western limb of the Kuroshio Current.

\section{Materials and Methods}

\subsection{SO202 INOPEX cruise study area}

Multinet and multicore samples from the SO202 INOPEX cruise (2009) with the German RV Sonne (Gersonde, 2012) were analysed from 15 North Pacific sites (6 multicore and 9 multinets) in combination with hydrographic CTD data (Table 1). The site locations range from the Subarctic Front through the Subpolar Gyre to the Bering Sea (Figure 1). The spatial variation between the sites means the diverse regional hydrography affects individual sites differently (Figure 1). Those lying within the Subarctic frontal region (sites SO202-02-40, SO202-05-34 and SO202-05-33) are predominantly bathed in waters derived from the westward extension of the Kuroshio Current. Sites SO202-04-27 and SO202-02-31 are influenced by the Alaskan Coastal Current, and sites SO202-05-02, SO202-02-06 and SO202-02-07 in the northwest Pacific are associated with the cooler Kamchatka Current and outflow from the Sea of Okhotsk. The Bering Sea sites (SO202-04-10, SO202-03-13, SO202-04-14, SO202-04-15), located along Bower's Ridge, the Aleutian Basin and proximal to the Bering Slope, are subject to inflow waters from the Alaskan Current and waters that form the initial stages of the Bering Slope Current. Data were also compiled from core-top sites spanning down to $20^{\circ} \mathrm{S}$ latitude.

\subsection{CTD deployments}

A Seabird 911 CTD device was used to record hydrographic conditions down to a depth of $6000 \mathrm{~m}$. The CTD was lowered through the water column at speeds of up to $0.5 \mathrm{~m} / \mathrm{s}$ and carried a fluorimeter to measure chlorophyll fluorescence and derive phytoplankton concentration. At multinet sites, temperature, salinity, oxygen and chlorophyll- $\alpha$ concentration (calculated from phytoplankton fluorescence) were recorded down to $1000 \mathrm{~m}$. The CTD data were usually collected within 3 hours of the multinet deployment and are available within the supplementary information and through the PANGAEA database.

\subsection{Multinet samples}

The multinet device collected samples at five depth intervals (1000-500 m; 500-300 m; 300-150 m; 150-50 $\mathrm{m}$ and 0-50 m) using a mesh size of $55 \mu \mathrm{m}$ and an aperture area of $0.25 \mathrm{~m}^{2}$ (Gersonde, 2012). The multinet was lowered to $1000 \mathrm{~m}$ depth and raised through the water column at a speed of 0.3 
$\mathrm{m} / \mathrm{s}$. Plankton samples were collected in cod end beakers ( 1 litre, $41 \mu \mathrm{m}$ mesh size) and then transferred into 1 litre bottles and fixed in a seawater solution containing $2 \%$ formalin by volume (formalin is $37 \%$ formaldehyde $\mathrm{w} / \mathrm{w}$ ) and buffered with hexamethylenetetramine at $\mathrm{pH}=8.1$ onboard. In preparation for foraminifera assemblage work, each depth interval was wet sieved between 160 $500 \mu \mathrm{m}$ to remove larger organisms. Foraminifera were then wet picked under the light microscope and all species were counted. For each depth interval, foraminifera standing stocks were calculated using equation 1 , where $\mathrm{Z}$ is the distance the multinet travelled through a particular interval:

Foraminifera standing stock $\left(\mathrm{m}^{3}\right)=(\#$ foraminifera $) /\left(\mathrm{Z}^{*} 0.25\right)$

No distinction was made between living and dead specimens.

\subsection{Surface sediment samples}

Multicore material from six new subpolar sites (Figure 1) was collected using a 12 tube $(60 \mathrm{~cm} \times 6 \mathrm{~cm}$ ) multicorer (MUC) (Gersonde, 2012). The samples represent the 1-2 cm interval from one tube and approximately $20 \mathrm{cc}$ of the sediment material was utilised to provide sufficient foraminifera for the assemblage counts. The core-material is stored at the Alfred Wegner Institute in Bremerhaven, Germany.

Samples were wet sieved $(63 \mu \mathrm{m})$ to remove the fine clay fraction, placed in a petri dish and dried in an oven at $<50{ }^{\circ} \mathrm{C}$ for $6-12$ hours. Following drying, the coarse fraction $(>63 \mu \mathrm{m})$ was transferred to a glass vial. The sample was then sieved at greater than $150 \mu \mathrm{m}$ and split with micro-splitter to greater than 300 planktic foraminifera, a number shown to provide an accurate assessment of relative abundance within an assemblage (Schiebel and Hemleben, 2017). Foraminiferal species were then counted using a stereo microscope and the percentage species abundances for each sample calculated (for taxonomy see supplementary information).

\subsection{Plankton net samples}

Plankton net samples were collected along a transect from Hawaii to Alaska during August 2017 as part of the CDisK-IV (KM1712) cruise on R/V Kilo Moana. The transect was designed to sample subtropical, transition zone and subpolar waters. A $0.5 \mathrm{~m}$ diameter net with $90 \mu \mathrm{m}$ mesh size was used throughout the cruise. The sampling strategy was designed to capture an integrated sample of all foraminifera living throughout the upper water column. The net was towed from the surface down to a specified maximum depth within the water column, and then back to the surface in a continuous manner. The maximum depth was determined from the florescence profile of a preceding CTD cast, and was selected to ensure the net sampling captured the base of the chlorophyll maximum, and ranged from $150 \mathrm{~m}$ in the north to $300 \mathrm{~m}$ in the south in these samples. After collection, samples were 
preserved in a $4 \%$ formalin seawater solution, buffered to a $\mathrm{pH}$ of $\sim 8.1$ with hexamethylenetetramine (Schiebel and Hemleben, 2017). Samples were split with a falsom splitter and all foraminifera $>125$ $\mu \mathrm{m}$ were identified to species level.

\subsection{Compilation of North Pacific core-top assemblage data}

To obtain an overview of the distribution pattern of planktic foraminifers preserved in North Pacific surface sediment record we merged our subarctic data set with previously published data from the subtropical Pacific, the Equatorial Pacific and the South China Sea presented in the MARGO database (Kucera et al. 2005) and by Coulbourn et al. (1980). The MARGO database was filtered to include only samples from the north and equatorial Pacific and the South China Sea. For consistency and accuracy, samples with fewer than 300 specimens were removed from the database. Substantial effort was made in this study to manually digitise the assemblage data from Coulbourn et al. (1980), and the same filtering parameters were used to select sites from this database. All three datasets were then combined to produce a new North Pacific planktic foraminifera assemblage database containing 770 sites.

For each of the 770 sites of our compilation, hydrographic data (temperature, salinity, oxygen and phosphate) was estimated using ODV's 3D estimation tool and the World Ocean Atlas 2013 (19552012) (Boyer et al. 2013). Mean annual surface water data was derived for surface temperature (Locarnini et al. 2013), salinity (Zweng et al. 2013), oxygen (Garcia et al. 2013) and phosphate content (Garcia et al. 2013).

\subsection{Sediment trap data}

We consider planktic foraminifera assemblage data from five previously published sediment trap sites in the North Pacific (Figure 1): sites 40N (1997-2000) and 50N (1997-2001) in the Northwest Pacific (Kuroyanagi et al. 2008); site SA in the central subpolar Pacific (Asahi and Takahashi, 2007) collected between 1990-1999; station PAPA in the Northeast Pacific (Sautter and Thunell, 1989) collected between 1982-1986 and site AB in the Bering Sea (Asahi and Takahashi, 2007) collected between 1990-1999 (Table 1). As sediment trap data was collected over multiple years, values were averaged to produce comparable datasets between sites. In these cases, the standard error was calculated to constrain annual variability.

\section{Results}

\subsection{Subarctic Front}

Sites SO202-05-33 and SO202-05-34 lie on the eastward extension of the Subarctic Front (Figure 1). Both sites exhibit highest foraminifera abundance within the top $50 \mathrm{~m}$ of the water column coinciding 
with maximum chlorophyll levels and a seasonal thermocline. Total foraminifera standing stocks at Site SO202-05-34 was high with 24.8 shells $/ \mathrm{m}^{-3}$ and lower at Site SO202-05-33 with 15.1 shells $/ \mathrm{m}^{-3}$ (Figure 2). Site SO202-05-34 has a much more diverse foraminiferal assemblage than SO202-05-33 and is dominated by 7 species: N. dutertrei (25\%), N. incompta (23\%), G. inflata (13\%), G. bulloides (8.9 $\%)$, T. quinqueloba (8.4 \%), N. pachyderma (8.3 \%) and G. siphonifera (6.8\%). Site SO202-05-34 shows the highest abundance of $N$. incompta and G. inflata for any of our multinets, reflecting the southerly location of this site. The more northerly Site SO202-05-33 is dominated by only three species: $G$. bulloides (74.8\%), N. pachyderma (12.5\%) and G. glutinata (8.1\%). Hydrographically, sites SO202-0533 and SO202-05-34 differ significantly, with site SO202-05-34 exhibiting higher SST (sea surface temperature) of $16.4^{\circ} \mathrm{C}$ compared with $13.3^{\circ} \mathrm{C}$ at site SO202-05-33. Surface salinity is higher at site SO202-05-34 (33.9 p.s.u compared to 32.8 p.s.u), reflecting the location of site SO202-05-34 at the northern rim of the subtropical gyre.

Core-top site SO202-02-40 is located further west than sites SO202-05-33 and SO202-05-34 and occupies the northern limb of the Kuroshio Current (Figure 1). Its assemblage is dominated by 5 species of planktic foraminifera: N. incompta (42.6\%), G. inflata (18.3\%), N. pachyderma (15.8\%), G. bulloides (9\%) and G. siphonifera (7.3\%) (Figure 2). As with site SO202-05-34, the high abundance of $N$. incompta, $G$. inflata and $G$. siphonifera reflect the warmer temperatures at this site. Plankton net assemblages from site St. 4 comprise of two main planktic foraminifera species, $N$. incompta $(46.2 \%)$ and N. dutertrei (42.6\%) (Figure 2). Site St. 4 is found on the Sub-arctic front (Figure 1).

\subsection{North East Pacific (Alaskan Coastal Current)}

Sites SO202-04-27 and SO202-02-31 are located in the North East Pacific, an area dominated by the Alaskan coastal current and the North East Pacific gyre (Figure 1). Total foraminiferal standing stocks at site SO202-04-27 is the highest of any of our multinets and is mainly confined to the first $50 \mathrm{~m}$ of the water column. Maximum foraminiferal abundance is clearly associated with high chlorophyll levels (Figure 2). In contrast, site SO202-02-31 in the centre of the gyre shows lower total foraminiferal standing stocks (5-10 shells $/ \mathrm{m}^{-3}$ ), with the highest flux coming in the 50-150 m depth interval. Chlorophyll levels here are markedly lower than at site SO202-04-27 (Figure 2). The proportionate assemblage of species at the two sites are also quite different. Site SO202-04-27 is characterised by only two species, G. bulloides (41.4\%) and N. pachyderma (50.3\%), while Site SO202-02-31 has significant abundances of four species: G. bulloides (44.8\%), N. pachyderma (20.5\%), G. glutinata (20.1\%) and T. quinqueloba (13.3\%). Core-top assemblage data from site SO202-02-31 shows a reduction in diversity compared to the multinet, with only two species with high abundance: $N$. pachyderma (67.9 \%) and G. bulloides (29.8\%). Both multinet and core-top counts from site SO202- 
04-27 are characterized by two species: N. pachyderma (50.28\% multinet, $93.68 \%$ core-top) and G. bulloides ( $41.4 \%$ multinet, $6.3 \%$ core-top) (Figure 2). Site St. 5 is located close to Station PAPA and site SO202-04-27 (Figure 1). It exhibits close to equal contributions from four species: N. pachyderma (33.2 \%); T. quinqueloba (24.4\%); N. incompta (23.7\%); G. bulloides (17.9 \%) (Figure 2).

Hydrologically the two sites exhibit similar surface oxygen and temperature $\left(11-12^{\circ} \mathrm{C}\right)$ values at the surface and high oxygen values down to $\sim 100 \mathrm{~m}$. Site SO202-02-31 has lower salinity (32.5 p.s.u.) at $10 \mathrm{~m}$ than Site SO202-04-27 (32.8 p.s.u), alongside greater numbers of foraminifera at 50-150m depth compared with 0-50 m at site SO202-04-27. There are major differences between the two sites in terms of chlorophyll. At site SO202-04-27, chlorophyll levels indicate a high phytoplankton bloom, peaking at around $50 \mathrm{~m}(0.7 \mu \mathrm{g} / \mathrm{L})$, which is double that of the maximum at site SO202-02-31 at $10 \mathrm{~m}$ $\operatorname{depth}(0.35 \mu \mathrm{g} / \mathrm{L})$.

\subsection{Sub-tropical gyre}

Plankton net St. 3 is located just below the Sub-arctic front. It is primarily influences by southbound waters of the Kuroshio Extension. Two species are present in high abundance in this sample: G. ruber (53.63\%) and N. incompta (31.88\%). Site St. 2 is located on the eastern limb of the sub-tropical gyre (Figure 1) and is characterised by six species of planktic foraminifera: T. sacculifer (24.21\%), G. ruber (24.21\%), G. crassaformis (14.74\%), G. siphonifera (12.63\%), G. calida (10. $53 \%$ ) and G. radians (7.37 \%) (Figure 2). Site St. 1 is located off the coast of Hawaii (Figure 1) and is characterised by five species: T. sacculifer (33.24\%), G. tenella (22.46\%), G. ruber (22.16\%), G. rubescens (7.78\%) and G. siphonifera (5.09\%) (Figure 2).

\subsection{North West Pacific (Kamchatka Current, Oyashio Current)}

Site SO202-05-02 is located in the North West Pacific and reflects hydrological influences from the Kamchatka and Oyashio currents with the addition of outflow water from the Sea of Okhotsk (Figure 1). Overall total foraminifera flux is low at site $\mathrm{SO202-05-02,} \mathrm{with} \mathrm{the} \mathrm{greatest} \mathrm{abundance} \mathrm{found} \mathrm{in} \mathrm{the}$ 0-50 $\mathrm{m}$ depth interval (Figure 2). Only three species are abundant ( $>5 \%$ ) in the multinet assemblage: N. pachyderma (70.7 \%), G. bulloides (16.5\%) and N. incompta (5.4\%). Compared to the North East Pacific, N. pachyderma is present in proportionately much greater numbers within the total assemblage. Chlorophyll levels peak at $35 \mathrm{~m}$ in the water column $(0.4 \mu \mathrm{g} / \mathrm{L})$, and SST is nearly $3^{\circ} \mathrm{C}$ colder than in the North East Pacific with a seasonal thermocline present in the first $50 \mathrm{~m}$. Similar to site SO202-02-31, site SO202-05-02 has a deep oxygen maximum down to $125 \mathrm{~m}$, reflecting a deeper winter mixed layer. 
Core-tops were collected from sites SO202-02-06 and SO202-02-07 also in the North West Pacific. Both sites indicate a dominance of $N$. pachyderma with site SO202-02-06 exhibiting $96.8 \%$ and no other species over $5 \%$ abundance. Site SO202-02-07 has $89.7 \%$ N. pachyderma with G. bulloides showing a relative abundance of $9.4 \%$ (Figure 2).

\subsection{Bering Sea (Alaskan Coastal inflow water, Bering slope water)}

Multinets SO202-04-10, SO202-03-13, SO202-04-14 and SO202-04-15 were collected in the Bering Sea between the Aleutian Islands and the Bering Slope (Figure 1). The sites are predominantly bathed in waters derived through inflow from the Alaskan Coastal Current as well as the initial stages of the Bering Slope current (Figure 1). Total foraminiferal flux was highest at sites SO202-04-14 and SO20203-13 where foraminifera populations were predominantly found in the top $50 \mathrm{~m}$ of the water column alongside chlorophyll- $\alpha$ levels of $0.2-0.4 \mu \mathrm{g} / \mathrm{L}$ (Figure 2). Both sites also exhibit a notable abundance of planktic foraminifera just below the chlorophyll maxima. Sites SO202-04-10 and SO202-04-15 show much lower standing stocks of foraminifera $\left(<5\right.$ shells $/ \mathrm{m}^{-3}$ ) (Figure 2$)$. In both cases, foraminifera are found slightly below the chlorophyll maxima in the 50-150 m depth interval (Figure 2). Sites SO20204-10, SO202-03-13 and SO202-04-14 are dominated by two species of planktic foraminifera. Site SO202-04-14 has $65.04 \%$ N. pachyderma and 32.3\% G. bulloides. Site SO202-03-13 has $52.9 \%$ N. pachyderma and $40.4 \%$ G. bulloides, whilst site SO202-04-10 has $54 \%$ N. pachyderma and $44.52 \%$ G. bulloides. Site SO202-04-15 is the only Bering Sea site to exhibit additional species $>5 \%$ in its assemblage: N. pachyderma (65.1\%), G. bulloides (25.6 \%) and G. glutinata (9.3\%). Core-top assemblage counts from site SO202-03-13 show a sole dominance of $N$. pachyderma (99.4\%).

Hydrographically, sites in the Bering Sea have similar water column profiles. Sea surface temperatures range from $7-8^{\circ} \mathrm{C}$ with a seasonal thermocline from 25-50 m. A key feature of Bering Sea sites is the very deep oxygen maximum zone, often extending below $200 \mathrm{~m}$, as well as low temperatures and salinities reflecting a deep winter mixed layer. Chlorophyll levels are low at sites SO202-03-13 and SO202-04-15 compared to the other multinets at sites SO202-04-10 and SO202-04-14 (Figure 2).

\section{Discussion}

We use our new data and compiled core-top database to re-evaluate planktic foraminifera faunal zones in the North Pacific. We also discuss dissolution bias within the sediment record and suggest that although North Pacific planktic foraminifera assemblages are influenced by dissolution, and specific species abundances within a sample may be biased, the overall pattern of faunal distribution is not seriously affected, and paleo-assemblages provide a particularly useful tool to track large-scale changes in surface ocean circulation. We then focus our discussion on the spatial, seasonal and depth 
distribution of the key proxy carrying species in the subpolar zone, N. pachyderma and G. bulloides. Understanding seasonal, spatial and water column drivers of abundance within these species is increasingly important with regards to interpreting both paleo-assemblage and geochemical data. A better understanding of these drivers will allow paleoceanographers to better use foraminiferal assemblages downcore to track changes in paleoenvironmental conditions. For geochemists, knowledge about seasonal preference and depth habitat are vitally important, particularly when reconstructing ocean conditions such as temperature and $\mathrm{pH}$.

\subsection{Geographic distribution of planktic foraminifera in the North Pacific}

In addition to N. pachyderma and G. bulloides, which dominate the subpolar zone, 8 other indicator species of planktic foraminifera define the other regional zones in the North and Equatorial Pacific (Figure 3). Bradshaw (1959) and Coulbourn et al. (1980) initially characterised 4 major faunal regions within the North Pacific: sub-arctic; transitional; central and equatorial. These were based predominantly on distributions of 5 species of planktic foraminifera: N. pachyderma, G. bulloides, $T$. quinqueloba, G. ruber and G. inflata (Bradshaw, 1959; Coulbourn et al. 1980). We suggest updated zones based on our larger compilation of core-top data. The faunal zones (subpolar, transitional, upwelling, subtropical, western equatorial and eastern equatorial) are broadly defined by the spatial distribution of N. pachyderma; G. bulloides; G. inflata; N. incompta; G. ruber; P. obliquiloculata; G. tumida; N. dutertrei; T. sacculifer; G. menardii (Figure 3). Although core-top assemblages may be somewhat affected by corrosive North Pacific waters, as defined below (surface water comparison) we find that dissolution has little effect on the overall pattern of faunal zones.

\section{Subpolar Zone}

The North Pacific subpolar zone is located north of the subpolar front at $40^{\circ} \mathrm{N}$ (Figure 3). It is defined by the subpolar gyre with its southern boundary occurring on the eastward limb of the Kuroshio current. Surface water temperatures in the subpolar zone range from $2-10^{\circ} \mathrm{C}$ (based on annual averages from WOA13). The subpolar zone is characterised by two species of planktic foraminifera: $N$. pachyderma which is found throughout the region, and G. bulloides which is most abundant in the Gulf of Alaska.

\section{Transitional Zone}

The transitional zone occupies the boundary between the subpolar and subtropical gyres (Figure 3). Surface waters flowing through this region are typically a mix of the Kuroshio and Oyashio currents (Yasuda, 2003). Annual average SSTs in the region are $8-15^{\circ} \mathrm{C}$ (WOA13). The transitional zone is characterised by two species of foraminifera: G. inflata, which exhibits the highest abundance in the 
transitional zone and $N$. incompta which is present in lower abundances. It is difficult to characterise the extension of this zone into the central Pacific, due to the lack of core-top sites with available foraminifera data. However, based on our multinet samples and those of Iwasaki et al. (2017), both species are prevalent across the central North Pacific along the Kuroshio extension. The link between the transitional zone and the subpolar front mean that changes in the abundance of these transitional species through time could be used as a sensitive tracer of gyre circulation and strength.

\section{Upwelling Zone}

In the North East Pacific, the Subarctic Front splits southward through the formation of the California current, a low temperature, low salinity current (Lynn and Simpson, 1987). This region is typified by significant upwelling, particularly during winter months (Huyer, 1983). N. incompta is most prevalent in this zone with G. bulloides and N. dutertrei also apparent (Figure 3).

\section{Subtropical Zones}

The subtropical zone represents the region between $35^{\circ} \mathrm{N}$ and $15^{\circ} \mathrm{N}$ in the North Pacific with an equivalent zone in the southern hemisphere (Figure 3). A warm water zone influenced by waters from the subtropical gyre with surface water temperatures between 18 and $27^{\circ} \mathrm{C}$ (WOA13), it is the most faunally diverse zone in the North Pacific in terms of planktic foraminifera. Species counts range from 7 to 29 (suppl. Figure 1), with G. ruber being the most consistently abundant species across the region (Figure 3). Other species include T. sacculifer, G. siphonifera, and G. calida.

\section{West Equatorial Zone}

The west equatorial zone is located between $15^{\circ} \mathrm{N}$ and $15^{\circ} \mathrm{S}$ in the North Pacific (Figure 3). Annual surface water temperatures range from $25^{\circ} \mathrm{C}$ to $30^{\circ} \mathrm{C}$ (WOA13). Two species of planktic foraminifera dominate in this region, P. obliquiloculata and G. tumida. P. obliquiloculata populations are thought to expand in response to winter temperatures (Tolderland and Bé, 1971) as well as living deep in the water column at depths of $200 \mathrm{~m}$. G. tumida, is not commonly observed within surface water samples and its high abundance within the sediment may be a result of dissolution bias. In addition to these two species, G. menardii and $T$. sacculifer are also present throughout this region in moderate abundances (Figure 3).

\section{East Equatorial Zone}

The East Equatorial zone refers to the region east of $140^{\circ} \mathrm{W}$ in the Equatorial zone (Figure 3). The region exhibits a broader temperature range than the West Equatorial zone $\left(20-30^{\circ} \mathrm{C}\right)$, due to seasonal changes in upwelling which bring cooler nutrient rich waters to the surface. The zone is dominated by 
N. dutertrei. N. dutertrei is thought to flourish in upwelling conditions near to gyre margins in warm tropical to subtropical waters (Imbrie and Kipp, 1971; Bé, 1977; Kroon and Ganssen, 1989; Brummer 2000)), which is consistent with very high abundance of $N$. dutertrei in the East Equatorial zone. $G$. menardii is also found in relatively high abundances in this region (Figure 3).

\section{Surface water comparison}

The zones described above are based on our compilation of surface sediment samples, which may be affected by dissolution. To test resemblance of surface water assemblages to these zones we analysed five plankton net samples from a transect spanning from Hawaii to Station PAPA in the North East Pacific during the CDISK-IV cruise (Figure 4). In addition, this transect fills a gap in the sediment record likely due to poor foraminiferal preservation (Figure 3).

The plankton net samples show good agreement with our proposed faunal zones. Site St. 1 in the Subtropical Zone shows high species diversity with the dominant species $G$. ruber and $T$. sacculifer, typical of this faunal zone. A high abundance of T. sacculifer and G. ruber is also found at site St. 2 which lies on the border between the transitional and subtropical zones. Sites St. 3 and St. 4 see a decrease in assemblage diversity with only two species in high abundance. The dominance of the transitional species $N$. incompta over $G$. inflata at this location (Figure 3), suggests $N$. incompta may be the dominant transitional species in the eastern Transitional zone. The $N$. dutertrei identified at the transitional site St. $4\left(41^{\circ} \mathrm{N}\right)$ is highly likely to be the cooler water $N$. dutertrei genetic type Ic, identified off the California coast by Darling et al, (2003) and reflects the warmer regional SSTs of the summer months. Site St. 5 shows a clear transition to Subpolar Zones species. N. pachyderma has the highest abundance, though is not as predominant as in the core-top data, likely due to the combination of warm summer collection temperatures and dissolution (see below).

The key differences between our net samples and the surface sediment compilation include higher diversity at mid to lower latitudes, greater abundance of smaller foraminifera, and increased abundance of some temperate species at mid to high latitudes (Figure 3 and 4). There are three reasons these differences might occur. Firstly, the smaller sampling size of $>125 \mu \mathrm{m}$ used in the plankton nets meant increased numbers of smaller species such as G. rubescens, G. tenella and $T$. quinqueloba were present. Secondly, the plankton net samples were collected during summer months where warmer surface waters allow the more temperate genetic types of both G. ruber (St. 3) and N. dutertrei (St. 4) to frequent the higher latitude waters (Darling et al, 2003; 2008). Thirdly, dissolution in corrosive North Pacific waters is likely to reduce diversity in sediment samples and bias samples somewhat towards dissolution resistant species. However, despite these potential biases, overall net samples show patterns consistent with core tops, adding confidence to this zonation. 


\subsection{Ecology and Distribution of G. bulloides in North Pacific waters}

G. bulloides is primarily found within the subpolar and transitional zones of the global ocean (Tolderlund and Bé, 1971; Bé and Hutson, 1977; Coulbourn et al. 1980), forming a substantial portion of mid to high latitude assemblages (Kucera, 2007). It can be found in association with both upwelling and non-upwelling regions (Curry et al. 1992; Darling et al. 2003; Davis et al. 2016; Mallo et al. 2017) and represents an important proxy carrier for paleoclimatic records (Schiebel and Hemleben, 2017). In the North Atlantic, G. bulloides has been observed to tolerate temperature ranges of between 5-30 ${ }^{\circ} \mathrm{C}$ (Źarić et al. 2005; Kucera, 2007). However much of this extreme temperature range may be explained by the presence of different cryptic species of G. bulloides (Darling et al. 2008), where different genotypes are adapted to different environmental conditions. It is therefore key that depth habitat, seasonality and ecology are regionally resolved for this species.

The relationship between the vertical distribution of $G$. bulloides and the physical state of the water column can be determined from our multinet data. Our data shows the highest $G$. bulloides standing stocks are between 0-50 m. In most cases, this coincides with maximum chlorophyll- $\alpha$ concentration in the water column (Figure 5), indicative of high food availability. This relationship is typified at site SO202-04-27 where G. bulloides peaks at 28.64 tests $/ \mathrm{m}^{-3}$ between $0-50 \mathrm{~m}$, the highest of any site in this study, with surface temperatures of $8^{\circ} \mathrm{C}(0-50 \mathrm{~m})$ and a chlorophyll- $\alpha$ peak of $0.7 \mu \mathrm{g} / \mathrm{L}$. Similarly, where surface chlorophyll- $\alpha$ is low, such as site S0202-02-31 (0.35 $\mu \mathrm{g} / \mathrm{L}), \mathrm{G}$. bulloides abundance is also low. This suggests that within the upper $50 \mathrm{~m}$ of the water column, G. bulloides abundance is primarily driven by food availability. Kuroyanagi and Kawahata (2004) also show G. bulloides predominantly residing between $20-40 \mathrm{~m}$ in the water column in the North West Pacific and Field (2004) link the peak occurrence of $G$. bulloides with chlorophyll maximum at sites along the California margin. Bird et al. (2017) cite G. bulloides as an opportunistic feeder, preying on zoo- and phytoplankton, as well as bacterioplankton.

A number of sites within this study indicate that some populations of $G$. bulloides may live deeper in the water column, below the chlorophyll maximum. Sites in the North East Pacific (SO202-04-27 and SO202-02-31), Bering Sea (SO202-04-10, SO202-03-13 and SO202-04-14) all have standing stocks of G. bulloides greater than 2 tests $/ \mathrm{m}^{-3}$ down to $150 \mathrm{~m}$ depths, whilst at site S0202-04-15 (the most northerly site in the Bering Sea), a small standing stock of G. bulloides occurs between $50-150 \mathrm{~m}$ (Figure 5). The exact size and prominence of these deeper dwelling populations are difficult to quantify as some specimens at our sites may represent deceased foraminifera which have recently sunk through the water column. Despite this, Iwasaki et al. (2017) indicate several North Pacific sites where deeper dwelling G. bulloides are observed (see supplementary information). Their study includes 5 
sites with $G$. bulloides abundances greater than 2 tests $/ \mathrm{m}^{3}$ between $50-100 \mathrm{~m}$ and 4 sites with $G$. bulloides $>100 \mathrm{~m}$ (Iwasaki et al. 2017) (see supplementary information). Both our sites and those cited by Iwasaki et al. (2017), indicate that $G$. bulloides can live below the chlorophyll maximum but at reduced abundances compared to the photic zone. At our sites, deep dwelling G. bulloides are associated with a deep oxygen maximum zone, reflecting deep winter mixing (Roden, 1985). Schiebel et al. (2001) and Freeland et al. (1997) suggest that a deeper mixed layer could increase the entrainment of deep water nutrients from intermediate waters into the mixed layer, a mechanism used to explain a deeper depth habit for G. bulloides by Iwasaki et al. (2017). This coupled with mixing of nutrient and food rich surface waters to depth could explain deeper dwelling G. bulloides at our sites. Recent work by Bird et al. 2017, which demonstrates the first observation of bacteria within $G$. bulloides type IId off California, also suggests that G. bulloides may use bacteria as a potential food source. This could help explain the survival of deeper dwelling populations, where light limits the availability of conventional food sources. Deeper dwelling G. bulloides are often found at our sites where surface waters $(0-50 \mathrm{~m})$ have lower salinity. This is particularly prevalent at site SO202-02-31 and could explain the deeper dwelling G. bulloides at this site, where salinity increases below the chlorophyll maximum (Figure 5). Despite the evidence that $G$. bulloides may inhabit waters below the chlorophyll maximum, it is important to stress that the majority of sites in this study show the maximum abundance of $G$. bulloides in the top $50 \mathrm{~m}$ of the water column (Figure 5), an important factor when interpreting geochemical and census data downcore.

To aid the interpretation of paleo-records, it is particularly important to understand the seasonal changes in oceanographic conditions which drive planktic foraminiferal abundance. Mean bi-weekly sampling of G. bulloides in sediment traps from the North West Pacific (Kuroyanagi et al. 2008) demonstrate the diverse seasonal hydrography of the region (sites $40 \mathrm{~N}$ and $50 \mathrm{~N}$, Figure 6). In the North West Pacific at $50^{\circ} \mathrm{N}$, G. bulloides is found throughout the year, with peak abundance occurring between April and June (Kuroyanagi et al. 2008). This represents the onset of the spring phytoplankton bloom, driven by reduced light limitation and increased stratification, combined with abundant nutrients that were previously brought to the surface by deep winter mixing (Kuroyanagi et al. 2008). This supports the use of $G$. bulloides as an indicator of productivity, a conclusion also reached by several recent modelling studies (Źarić et al. 2005; Fraile et al. 2008; Lombard et al. 2011; Jonkers and Kučera, 2015). Despite an increase in $N$. pachyderma flux during this period, the relative abundance, and overall flux, of $G$. bulloides still increases. Although this effect is muted, it further supports the use of $G$. bulloides relative abundance in tracking changes in productivity in the past. The G. bulloides flux at $40^{\circ} \mathrm{N}$ (site $40 \mathrm{~N}$ ) in the North West is more variable than at site $50 \mathrm{~N}$, with two abundance peaks occurring in winter (November-February) and in late spring (April-May) (Figure 6). Although organic 
matter flux peaks from July through to October, it does not correlate with the peaks in G. bulloides abundance (Kuroyanagi et al. 2008) (Figure 6). This variability is likely caused by the fact that the sediment trap lies on the interface between the Oyashsio (cold) and Kuroshio (warm) currents. This zone is characterised by strong eddy activity as well as influence from minor currents such as the Tsushima Warm Current (Yasuda, 2003). Horizontal transport of nutrients from rich subpolar waters, driven primarily by intra-annual wind stress variability (Ayers and Lozier, 2010), add to the confluence of ecological signals around the Kuroshio extension. The variable influences of these different systems are likely to drive the variability in annual $G$. bulloides flux, making it difficult to disentangle a particular driver of flux at this latitude. In addition, the high SSTs observed throughout the year at Site $40^{\circ} \mathrm{N}$ is likely to contribute to the lack of $G$. bulloides flux seen here in comparison with the other more northerly sites.

Sediment trap data from the central North Pacific and Bering Sea also show G. bulloides abundances associated with spring and summer increases in productivity, with very low abundances recorded during winter months (December to March) (Asahi and Takahashi, 2007). Peaks in G. bulloides in both traps tend to track increases in organic matter flux (Asahi and Takahashi, 2007), again suggesting a preference for eutrophic environments. This relationship is demonstrated by the prominent increase in G. bulloides relative abundance at the onset of the spring bloom in the Bering Sea. In the North East Pacific at Station PAPA, sediment trap data shows very low G. bulloides abundance over a four year period (Reynolds and Thunell, 1989). Small increases in G. bulloides were observed during April and May, in line with a small rise in organic matter flux, suggesting ties to food availability. However, no response in $G$. bulloides abundance was observed during the large increase in organic matter between August and September (Figure 6), which may imply summer temperatures $\left(>12.5^{\circ} \mathrm{C}\right.$ ) at this site rise above those tolerated by $G$. bulloides. The large increase in organic matter at station PAPA could also represent a plankton bloom of little dietary use to G. bulloides. Across the Pacific, the seasonal abundance of $G$. bulloides is largely tied to phytoplankton blooms and food availability, with $G$. bulloides numbers minimal or absent during the winter months, when organic matter flux is very low. The relative abundance of $G$. bulloides responds positively to the onset of the spring phytoplankton bloom, particularly at the higher latitude sites. Conversely, when assemblages become more diverse at lower latitude sites, this signal is muted.

G. bulloides has often been linked to upwelling zones (Reynolds and Thunell, 1980; Thiede, 1975; Sautter and Thunell, 1992; Field, 2004). However, its affinity with upwelling conditions in the North East Pacific is debated within recent literature. In the North-East Pacific, increased G. bulloides flux was observed during upwelling conditions (Reynolds and Thunell, 1980; Thiede, 1975; Sautter and Thunell, 1992; Field, 2004). However, other studies cite little dependence of G. bulloides on upwelling 
(Davis et al. 2016; Iwasaki et al. 2017). The recent work by Davis et al. (2016) from the North Pacific showed decreased abundance of $G$. bulloides during periods of enhanced mixing on the central California shelf. In this region, upwelling is characterised by nutrient rich cold waters which may be below the temperature tolerance of G. bulloides type Ild, leading to a reduction in abundance despite high nutrient levels.

The discovery of several genetically distinct genotypes of $G$. bulloides now sheds new light on the wide-ranging ecologies of regionally distributed G. bulloides (Figure 7). Globigerina bulloides genotypes fall into two clear highly divergent groups which are related to their ecologies (Darling \& Wade, 2008; Morard at al, 2013; Darling et al. 2017). The Type I genotypes (2 types) are associated with warmer waters and the Type II genotypes (7 types) are associated with cooler high latitude and transitional upwelling waters. The full temperature-specific range of the $G$. bulloides genotypes identified to date is shown in Sadekov et al. (2016). Three genotypes have been identified in the North Pacific, two of which are potentially endemic to the region (Fig. 6). The first is the transitional genotype Type IId, which has only been identified to date in the California Current (Darling et al, 2003). The second is genotype Type lle, which has only been identified in the subpolar waters of the North Pacific and Bering Sea at latitudes greater than $40^{\circ} \mathrm{N}$ (Darling et al. 2007). A single specimen of the subpolar and transition North Atlantic and Southern Ocean genotype Type Ila was identified off California in January (Darling et al, 2003), which possibly represents the winter population in the region (Davis et al, 2016). Uncertainty regarding the upwelling affinity of North Pacific G. bulloides is likely due to the differing ecological preferences of these different genotypes.

The separation of transitional and sub-polar genotypes is clearly demonstrated within our assemblage compilation. When the abundance of $G$. bulloides is plotted alongside SST, two clear populations can be seen (Figure 8). A mid-latitude population with a temperature range of $14.5-30^{\circ} \mathrm{C}$ is likely to represent the genotype IId and a high-latitude population with a temperature range of $5-14.5^{\circ} \mathrm{C}$ represents genotype lle (Figure 8). Examples of G. bulloides as upwelling indicators in the North East Pacific are predominantly constrained to latitudes between $30-35^{\circ} \mathrm{N}$ (Sautter and Thunell, 1992; Field, 2004). Only genotype Ild has been found at these latitudes in both upwelling waters and more stable summer water columns in the Santa Barbara Channel (Darling et al, 2003).

\subsection{Ecology and Distribution of N. pachyderma in the subpolar North Pacific}

N. pachyderma is found in high abundance in the polar and subpolar oceans and is frequently found in association with upwelling systems in the mid to low latitudes (Darling et al, 2017). Eight cryptic genotypes are currently recognised which are regionally distributed (Darling and Wade, 2008; Darling 
et al, 2017). Type I dominates the Arctic and North Atlantic oceans, Type II, III and IV are found only in the Antarctic water masses. Types V and VI appear isolated within the Benguela upwelling system, Type VII within the eastern North Pacific and Type VIII off the Oman margin in the Arabian Sea (Figure 7; Darling and Wade, 2007; Darling et al, 2017). There are clear ecological differences between the different cryptic species of $N$. pachyderma (Darling et al, 2004), and this is particularly important in the Antarctic region where 3 genetically distinct genotypes have been identified, with little morphological difference to separate them (Darling and Wade, 2008). As yet, genotyping coverage of the North Pacific subpolar region is incomplete in the far western region, but only one genotype of $N$. pachyderma (Type VII) has been identified to date throughout the eastern region and the Bering Sea (Darling et al, 2007). It would be expected that the anticlockwise subpolar gyre circulation (Figure 1) would also carry the N. pachyderma Type VII into western subpolar waters.

The vertical distribution of $N$. pachyderma in North Pacific waters varies with regional hydrography (Figure 9). The North East Pacific is typified by site SO202-04-27, where cool summer surface temperatures $\left(10^{\circ} \mathrm{C}\right)$ combine with high chlorophyll- $\alpha$ levels and a shallow seasonal thermocline. Here, N. pachyderma is most abundant in the top $50 \mathrm{~m}$ of the water column. N. pachyderma is also found at 0-50 $\mathrm{m}$ in the Bering Sea, where low chlorophyll- $\alpha$ is compensated for by cold surface temperatures (7-8 $\left.{ }^{\circ} \mathrm{C}\right)$ which are optimal for N. pachyderma (Reynolds and Thunell, 1986, Kuroyanagi and Kawahata, 2004). Although N. pachyderma responds most consistently to cool surface temperatures $\left(<10^{\circ} \mathrm{C}\right)$, it can flourish in warmer surface waters $\left(10-14^{\circ} \mathrm{C}\right)$ when food availability is high (site SO202-04-27). Kuroyanagi and Kawahata (2004) argue that N. pachyderma abundance is associated with the pycnocline in the North West Pacific. Within our sites, there is some evidence of high N. pachyderma abundance within the shallow seasonal pycnocline, a region also commonly associated with high chlorophyll- $\alpha$ values. Overall, our sites suggest that $N$. pachyderma vertical abundance distribution is controlled primarily by food availability, but they can also flourish in cooler temperatures where competition for food is likely to be limited. Spatially $N$. pachyderma abundance is strongly linked to temperature in the North Pacific (Figure7a). This striking relationship provides excellent evidence that percentage abundance $N$. pachyderma can be used to track qualitative changes in temperature downcore.

N. pachyderma is also observed to live deeper in the water column at our sites as well as those published by Iwasaki et al. (2017) (Figure 9 and supplementary information). This is particularly prevalent in the Bering Sea, where 3 sites show $>2 \mathrm{~m}^{-3}$ abundance between 50-150 $\mathrm{m}$. In the North West Pacific three sites from Iwasaki et al. (2017) show N. pachyderma living down to $300 \mathrm{~m}$ in the water column (see supplementary information). As with $G$. bulloides, where deep dwelling $N$. pachyderma are observed in our multinets they are commonly associated with deep oxygen maxima 
and a deep winter mixed layer. This could be a result of increased winter mixing bringing up nutrient rich waters (Schiebel et al. 2001; Iwasaki et al. 2017), as well as mixing of food (phytoplankton) from the surface waters down to depth. Nutrients are higher in general throughout the year in the North West Pacific and are higher still during winter months (Garcia et al. 2013). In addition, deeper dwelling populations could be linked to low surface salinities at 0-50 $\mathrm{m}$, which may be outside the preferential salinity range of $N$. pachyderma. Interestingly, King and Howard (2003) found that N. pachyderma in the Southern Ocean could live down to depths of $200 \mathrm{~m}$ when the mixed layer was deep, allowing deeper penetration of food and nutrients. A combination of these mechanisms may be present in the North Pacific and explain why some of our sites show an increase of deep dwelling N. pachyderma and G. bulloides at locations where a deep-winter mixed layer is observed (Figure 9). However, overall our sites suggest a predominantly near surface habitat $(0-50 \mathrm{~m})$ for $N$. pachyderma which is reflected in other studies from this region (Kuroyanagi et al. 2004; Iwasaki et al. 2017), as well as the North Atlantic (Pados and Spielhagen, 2014) and Southern Ocean (King and Howard, 2003; Kohfeld et al. 1996).

In the subpolar North West Pacific, N. pachyderma is abundant throughout the year and peaks predominantly during the spring phytoplankton bloom between April and May when organic matter flux is high (Kuroyanagi et al. 2008) (Figure 6). Only during later summer months does N. pachyderma abundance drop whilst organic matter flux remains high (Figure 6), possibly reflecting SST's that are above the ecological range for this species. On the subpolar front at $40^{\circ} \mathrm{N}$ latitude, $N$. pachyderma again peaks between April and May. Its abundance throughout the rest of the year is very low, reflecting SST as the limiting factor in N. pachyderma abundance. In the North East Pacific, subpolar seasonal trends in N. pachyderma mirror those in the west, but with a lower overall abundance (Sautter and Thunell, 1989). Predominantly, high abundances occur during spring (March-April) and tail off into summer months as SSTs rise. A second increase in N. pachyderma occurs during November, where N. pachyderma may be responding to a combination of low SSTs and reduced competition for food as light and temperature limit productivity.

As a subpolar species, N. pachyderma relative abundance in the North Pacific is tied closely to temperature (Figure 8) and latitude. Darling et al. (2004 and 2007) cite a temperature range of 3 to 14 ${ }^{\circ} \mathrm{C}$, which correlates well with relative abundance seen in our core-top compilation, whilst Kuroyanagi and Kawahata (2004) cite $5-8^{\circ} \mathrm{C}$ as the optimum temperature range for $N$. pachyderma. We find a temperature tolerance of up to $16^{\circ} \mathrm{C}$, at which point $N$. pachyderma relative abundance drops below $10 \%$ (Figure 8). We also find that at $<8^{\circ} \mathrm{C}$, a temperature suggested by Reynolds and Thunell (1986) and Kuroyanagi and Kawahata (2004) as being close to optimum conditions, N. pachyderma has relative abundance of $>50 \%$ (Figure 8 ). It is important to note that $N$. pachyderma abundance is also likely to be controlled partly by the temperature tolerance of its food source. 


\subsection{Dissolution and seasonality in North Pacific core top assemblages}

Preferential dissolution of certain species of planktic foraminifera in seafloor sediment samples has the potential to bias paleo-assemblage data. By comparing core-tops and multinets from the same and nearby sites, we observe possible dissolution driven increase in $N$. pachyderma over G. bulloides abundance in core-top sediments, with up to 31\% reduction (Site SO202-03-13, Bering Sea) in G. bulloides and up to $44 \%$ increase in N. pachyderma (Figure 10). Differences between multinet and core-top assemblages could be driven by two factors: dissolution or seasonality. We tested the possible effect of seasonality on our multinet samples by comparing annual sediment trap assemblages with assemblages based only on July-August (the time when our multinet were collected) (Figure 10 and 11). Figure 11 highlights a lack of obvious offset between summer and annual assemblages allowing us to conclude that the major driver of change within our core-tops is dissolution. In the North Pacific, under-saturated deep waters offer the potential to assess the influence of dissolution (Berger et al. 1982), especially in combination with abundance data from tows and sediment traps. Sautter and Thunell (1989) also reported an increase in N. pachyderma relative to other species when comparing sediment trap samples to core-top samples, and although they rule out water column dissolution through analysis of surface and deep trap material, it is likely that sediment pore-water dissolution does take place. Despite being widely prevalent in the compiled sediment trap data (Figure 10), T. quinqueloba is absent from the majority of our multinet and coretop samples. Whilst this may partly be reflecting dissolution of small $T$. quinqueloba specimens in corrosive North Pacific deep waters, it is more likely that the smaller sieve size used in sediment trap studies $(>125 \mu \mathrm{m})$ compared with core-top studies $(>150 \mu \mathrm{m})$ causes the offset. The fact that both surface water (multinet) and sediment (core-top) samples show a lack of $T$. quinqueloba further illustrates this point.

Assessment of dissolution in the deep North Pacific was previously attempted by Coulbourn et al. (1980), through similarity assessments of well-preserved near surface samples to samples situated deeper in the water column. Species were also ranked for dissolution resistance by region, allowing for dissolution indices to be calculated for each core-top sample (Coulbourn et al. 1980). Coulbourn et al. (1980) rank N. pachyderma and G. bulloides as 1 and 5 respectively, with 1 being highly dissolution resistant, suggesting that $N$. pachyderma's more compact test morphology could leave it less susceptible to dissolution, as suggested by our dataset. The overarching outcome from Coulbourn et al. (1980) is that dissolution is complex and difficult to account for in marine sediments and is likely to increase the error on transfer functions derived from assemblages, as well as skew potential ecological observations. However local dissolution analysis from the Western Equatorial Pacific suggests that although dissolution above $3000 \mathrm{~m}$ does occur, it has only minor influence on 
assemblages (Berger et al.1982). Below 3400 m, Berger et al. (1982) note that dissolution is more pronounced and that assemblages below $4000 \mathrm{~m}$ should be classed as residual assemblages and reflect the impacts of higher dissolution. Similarly, a water column dissolution experiment by Peterson (1966) cites a depth of $3700 \mathrm{~m}$ for the onset of increased dissolution in central North Pacific sediments. Within our dataset we see substantial changes in assemblage at considerably shallower depths (1383 m) than reported by Berger et al. (1982) and Peterson (1966). This is likely due to the highly corrosive nature of intermediate depth water in the North Pacific. The overall impact of dissolution on faunal assemblages in planktic foraminifera is a bias towards the preservation of dissolution resistant species (Ruddiman et al. 1967) such as N. pachyderma, G. inflata and N. dutertrei in the North Pacific (Schiebel and Hemleben, 2017). This has the potential to bias estimates of surface hydrography based on assemblage and should be taken into account when interpreting such records.

\section{Conclusions and implications for downcore records}

\subsection{Ecological drivers in subpolar species}

Analyses of new core-top and multinet data in combination with published core-top, sediment trap and multinet data allow us to better constrain the ecological drivers of the two key subpolar species of planktic foraminifera G. bulloides and N. pachyderma in the North Pacific.

In the subpolar North Pacific, G. bulloides is tied closely to food availability in the water column and is largely associated with the chlorophyll maximum. This trend is also observed within sediment trap data, where seasonal decreases in organic matter flux are associated with very low G. bulloides abundance. The use of $G$. bulloides relative abundance is therefore a useful productivity indicator for downcore interpretation. However, it is important to note that abundance of $N$. pachyderma is also tied to food availability and thus the percentage abundance of $G$. bulloides may not necessarily respond prominently to changes in food availability or productivity in the region, as both species may respond in parallel. Additional proxies such as percentage opal or temperature proxies used alongside relative abundance provide the best combination to obtain a more meaningful interpretation of the G. bulloides data within paleo-records. The calculation of mass accumulation rates (MAR) or planktic foraminifera per gram of sediment may also allow for a more robust use of $G$. bulloides when interpreting productivity changes.

The close relationship between N. pachyderma and temperature in the North Pacific (Figure 8) is striking. Multinet data demonstrates that N. pachyderma can flourish in colder waters even when food availability is low, likely due to decreased competition. This relationship is further demonstrated in our core-top compilation, where the largest relative N. pachyderma abundances are recorded in the 
coldest waters. We estimate a temperature range for the North Pacific subpolar N. pachyderma of 4$16{ }^{\circ} \mathrm{C}$, with relative abundance dropping below $50 \%$ at $>8^{\circ} \mathrm{C}$. Food availability also controls $N$. pachyderma numbers, but it is less important than with G. bulloides. As with G. bulloides, calculating planktic foraminifera accumulation rates may be the best way to assess the significance of paleoassemblages.

A key feature of our core-top compilation is the existence of a species-specific transitional zone occupying the region between the subpolar and subtropical gyres. The domination of G. inflata and $N$. incompta provide a potential tool to assess the strength and position of the two gyres in the past. For core sites located within the transition zone, any shifts in assemblage away from these species could be used to interpret influences from waters derived from either the subtropical or subpolar gyre.

\subsection{Implications for geochemical records}

Accurate use of geochemical proxies in planktic foraminifera requires knowledge of their ecology, particularly depth habitat and seasonality. The subpolar genotype of $N$. pachyderma found in the North Pacific, resides predominantly in the top $50 \mathrm{~m}$ of the water column and is likely to reflect nearsurface conditions. Where a deeper depth habit is observed, it is associated with a deep winter mixed layer, homogenising the water column such that conditions remain similar to those in the surface. Seasonally N. pachyderma flux does vary regionally, however, it often exhibits peaks in abundance during spring and late summer/autumn. The similarity in temperature during these two periods gives further credibility to the use of $N$. pachyderma in paleo-temperature reconstructions.

G. bulloides is often used to reconstruct sea surface temperatures through $\mathrm{Mg} / \mathrm{Ca}$ ratios. We find that G. bulloides predominantly resides in the top $50 \mathrm{~m}$ of the water column and is therefore likely to record sea surface conditions. Seasonal deep mixing also allows it to frequent greater depths, but at lower abundances. Seasonally, G. bulloides blooms in both spring and late autumn in the subpolar North Pacific. However, temperature signatures observed at these periods are not dissimilar and should not discourage geochemists from using G. bulloides to reconstruct sea surface temperatures down core. Two genotypes of G. bulloides dominate the North Pacific waters (Types Ile and IId), of these, Type Ile is confined to the subpolar zone whilst Types Ild is found off the California margin throughout the year in both upwelling and non-upwelling waters (Darling et al. 2003). However, the genotype Type lla has been identified in the winter in the south eastern coastal zone and is thought a potential member of the winter assemblage (Davies et al, 2017). It is therefore important to note that when analysing foraminifera on the boundary of these zones, multiple genotypes of ecologically distinct G. bulloides may be present in the assemblage. 


\subsection{Dissolution bias in sediments}

Planktic foraminifera abundance and flux have been widely used as proxies for paleoenvironmental change (Bond et al. 1993; Barker et al. 2009; Barker et al. 2015). In the Atlantic and Southern oceans, true polar conditions are achieved at high latitudes, normally resulting in $95-100 \%$ abundance of $N$. pachyderma during cold periods (Bond et al. 1993) with increased abundances of transitional and warmer water species (G. bulloides, G. inflata, G. ruber, G. hirsuta) occurring during warm timeintervals such as the Bølling-Allerød (Baker et al. 2009). Our comparison of North Pacific core-tops to multinets from the same region shows preferential preservation of $N$. pachyderma over more dissolution prone species such as $G$. bulloides. This has the potential to bias reconstructions that suggest more abundant polar waters during stadial conditions in the Atlantic (Bond et al. 1993), especially if these are accompanied with influx of more corrosive waters at depth. This warrants increased caution when assessing paleo-assemblage records, particularly at sites where deep water masses are known to be corrosive. Despite this, we find that broadly our defined faunal zones are unaffected by dissolution, however the details of assemblages within zones are more susceptible to dissolution bias.

\section{Acknowledgments}

We thank the crew of the scientific research vessel Sonne and those who participated in the $\mathrm{SO}^{202}$ INOPEX cruise for their assistance with the collection of multinet samples. We thank the crew of the Kilo Moana and science team of CDISK-IV (KM1712), led by Will Berelson and Jess Adkins, for their assistance with the collection of the plankton tows and an enjoyable cruise. We also thank members of the CALMED project (CTM2016-79547-R), and the Generalitat de Catalunya (MERS, 2017 SGR 1588). We are also thankful to all the people at the Alfred Wegner Institute who helped prepare the multinet samples, and to Heidi Block, Alasdair Murphy, Rory Abernathy, and Joshua Cook for assistance in preparing CDISK-IV net samples in the St Andrews lab. Funding was providied through a NERC Research Training Support Grant awarded NE/L002590/1 to Ben Taylor and NERC grant NE/N011716/1 awarded to James Rae and Andrea Burke. All supplementary data related to this article can be found within the supplementary information and is available on the PANGAEA database.

\section{References}

Asahi, H. \& Takahashi, K., 2007. A 9-year time-series of planktonic foraminifer fluxes and environmental change in the Bering sea and the central subarctic Pacific Ocean, 1990-1999. Progress in Oceanography, 72(4), pp.343-363.

Ayers, J.M. \& Lozier, M.S., 2010. Physical controls on the seasonal migration of the North Pacific transition zone chlorophyll front. Journal of Geophysical Research: Oceans, 115(5), pp.1-11. 
Barker, S. et al. 2015. Icebergs not the trigger for North Atlantic cold events. Nature, 520(7547), pp.333-336.

Barker, S. et al. 2009. Interhemispheric Atlantic seesaw response during the last deglaciation. Nature, 457, pp.1097-1102.

Bé, A.W.H. \& Hutson, W.H., 1977. Ecology of Planktonic Foraminifera and Biogeographic Patterns of Life and Fossil Assemblages in the Indian Ocean Ecology of planktonic foraminifera and biogeographic patterns of life and fossil assemblages in the Indian Ocean. Micropaleontology, 23(4), pp.369-414.

Berger, W.H., 1970. Planktonic Foraminifera: Selective solution and the lysocline. Marine Geology, 8(2), pp.111-138.

Berger, W.H., Bonneau, M.--C. \& Parker, F.L., 1982. Foraminifera on the deep-sea floor: lysocline and dissolution rate. Oceanologica acta, 5(2), pp.249-258.

Bond, G., Broecker, W., Johnsen, S., McManus, J., Lbeyrie, L., Jouzel, J., Bonani, G. 1993. Correlations between climate records from North Atlantic sediments and Greenland ice. Nature, 363, pp.143-147.

Bradshaw, J.S., 1959. Ecology of living planktonic foraminifera in the North and equatorial Pacific Ocean. Foraminiferal Research, 10, pp.25-64.

Conan, S.M.H., Brummer, G.J.A., 2000. Fluxes of planktic foraminifera in response to monssonal upwelling on the Somalia Basin margin. Deep Sea Research Part II: Tropical Studies in Oceanography. 47(9-11), pp. 2207-2227.

Coulbourn, W.T., Parker, F.L. \& Berger, W.H., 1980. Faunal and solution patterns of planktonic foraminifera in surface sediments of the North Pacific. Marine Micropaleontology, 5, pp.329399.

Curry, W.B. et al. 1992. Foraminiferal production and monsoonal upwelling in the Arabian Sea: evidence from sediment traps. Geological Society, London, Special Publications, 64(1), pp.93106.

Darling, K.F. et al. 2003. Seasonal distribution of genetic types of planktonic foraminifer morphospecies in the Santa Barbara Channel and its paleoceanographic implications. Paleoceanography, 18(2), pp.1-10.

Darling, K.F. et al. 2004. Molecular evidence links cryptic diversification in polar planktonic protists to Quaternary climate dynamics. Proceedings of the National Academy of Sciences, 101(20), pp.7657-7662.

Darling, K.F. et al. 2006. A resolution for the coiling direction paradox in Neogloboquadrina pachyderma. Paleoceanography, 21(2), pp.1-14.

Darling, K.F., Kucera, M. \& Wade, C.M., 2007. Global molecular phylogeography reveals persistent Arctic circumpolar isolation in a marine planktonic protist. Proceedings of the National Academy of Sciences of the United States of America, 104(12), pp.5002-5007.

Darling, K.F. \& Wade, C.M., 2008. The genetic diversity of planktic foraminifera and the global distribution of ribosomal RNA genotypes. Marine Micropaleontology, 67(3-4), pp.216-238.

Darling et al, 2017. Genetic diversity and ecology of the planktonic foraminifers Globigerina bulloides, Turborotalita quinqueloba and Neogloboquadrina pachyderma off the Oman margin during the late SW Monsoon. Marine Micropaleontology, 137, pp. 64-77.

https://doi.org/10.1016/j.marmicro.2017.10.006. 
Davis, C. V. et al. 2016. Seasonality in Planktic Foraminifera of the Central California Coastal Upwelling Region. Biogeosciences Discussions, pp.5139-5150.

Eguchi, N.O. et al. 2003. Seasonal variations in planktonic foraminifera at three sediment traps in the Subarctic, Transition and Subtropical zones of the central North Pacific Ocean. Marine Micropaleontology, 48(1-2), pp.149-163.

Fairbanks, R.G. et al. 1982. Vertical distribution and isotopic fractionation of living planktonic foraminifera from the Panama Basin. Nature, 298(5877), pp.841-844.

Fairbanks, R.G. \& Wiebe, P.H., 1980. Forminifera and chlorophyll maximum: Vertical distribution, seasonal succession and paleoceanographic distributuion. Science, 209(4464), pp.1524-1526.

Fenton, I.S. et al. 2016. Environmental Predictors of Diversity in Recent Planktonic Foraminifera as Recorded in Marine Sediments. Plos One, 11(11).

Field, D.B., 2004. Variability in vertical distributions of planktonic foraminifera in the California current: Relationships to vertical ocean structure. Paleoceanography, 19(2).

Fraile, I. et al. 2008. Predicting the global distribution of planktonic foraminifera using a dynamic ecosystem model. Biogeosciences. 5, pp. 891-911.

Freeland, H. et al. 1997. Evidence of change in the winter mixed layer in the Northeast Pacific Ocean. Deep Sea Research Part I: Oceanographic Research Papers, 44(12), pp.2117-2129.

Garcia, H.E. et al. 2014. World Ocean Atlas 2013, Volume 4 : Dissolved Inorganic Nutrients (phosphate, nitrate, silicate). NOAA Atlas NESDIS 76, 4(September), p.27.

Gersonde, R. 2012. The Expedition of the Research Vessel "Sonne" to the subpolar North Pacific and the Bering Sea in 2009 (SO202-INOPEX). Reports on Polar and Marine Research 643, 323 pp (http://epic.awi.de/30138/).

Harrison, P.J. et al. 2004. Nutrient and plankton dynamics in the NE and NW Gyres of the subarctic Pacific Ocean. Journal of Oceanography, 60(3), pp.93-117.

Hemleben, C., Spindler, M. \& Anderson, R.O., 1989. Modern Planktonic Foraminifera, Springer-Verlag New York Inc.

Huyer, A., 1983. Coastal upwelling in the California Current System. Progress In Oceanography, 12(3), pp.259-284.

Imbrie, J. \& Kipp, N., 1971. A new micropalaeontological method for quantitiative paleoclimatology: Application to late Pleistocene Carribean core V28-238. In K. K. Turekian, ed. The late Cenozoic Glacial Ages. Yale Univ. Press, New Haven, Conn, pp. 77-181.

Iwasaki, S. et al. 2017. Horizontal and vertical distributions of planktic foraminifera in the subarctic North Pacific. Marine Micropaleontology.

Jonkers, L. \& Kucera, M., 2015. Global analysis of seasonalitiy in the shell flux of extant planktonic Foraminifera. Biogeosciences. 12, pp. 2207-2226.

Kandiano, E.S. \& Bauch, H.A., 2002. Implications of planktic foraminiferal size fractions for the glacial-interglacial paleoceanogeaphy of the polar North Atlantic. Journal of Foraminiferal Research. 22(3).

King, A.L. \& Howard, W.R., 2003. Planktonic foraminiferal flux seasonality in Subantarctic sediment traps: A test for paleoclimate reconstructions. Paleoceanography, 18(1), pp.1-17.

Kohfeld, K.E. et al. 1996. Neogloboquadrina pachyderma (sinistral coiling) as paleoceanographic 
tracers in polar oceans: Evidence from northeast water polynya plankton tows, sediment traps, and surface sediments. Paleoceanography, 11(6), pp.679-699.

Kroon, D., Ganssen, G., 1989. Northern Indian Ocean upwelling cells and the stable isotope compostiion of living planktonic foraminifers. Deep Sea Research Part A. Oceanographic Research Papers. 36(8), pp. 1219-1236.

Kucera, M., 2007. Planktonic Foraminifera as Tracers of Past Oceanic Environments. In Proxies in Late Cenozoic Paleoceanography. pp. 213-262.

Kucera, M. et al. 2005. Reconstruction of sea-surface temperatures from assemblages of planktonic foraminifera: Multi-technique approach based on geographically constrained calibration data sets and its application to glacial Atlantic and Pacific Oceans. Quaternary Science Reviews, 24(7-9 SPEC. ISS.), pp.951-998.

Kuroyanagi, A. et al. 2002. Seasonal changes in plankotnic foraminifera in the North Pacific Ocean: sediment trap experiments from subarctic and subtropical gyres. Deep-Sea Research II, 49, pp.5627-5645.

Kuroyanagi, A. et al. 2008. Seasonal to interannual changes in planktonic foraminiferal assemblages in the northwestern North Pacific: Sediment trap results encompassing a warm period related to El Niño. Palaeogeography, Palaeoclimatology, Palaeoecology, 262(1-2), pp.107-127.

Kuroyanagi, A. \& Kawahata, H., 2004. Vertical distribution of living planktonic foraminifera in the seas around Japan. Marine Micropaleontology, 53(1-2), pp.173-196.

Locarnini, R.A. et al. 2013. World Ocean Atlas 2013. Vol. 1: Temperature. S. Levitus, Ed., A. Mishonov Technical Ed.; NOAA Atlas NESDIS 73, pp. 40.

Lombard, F. et al. 2011. Modelling planktic foraminifer growth and distribution using an ecophysiological multi-species approach. Biogeosciences. 8, pp. 853-873.

Lynn, R.J. \& Simpson, J.J., 1987. The California Current system: The seasonal variability of its physical characteristics. Journal of Geophysical Research, 92(C12), p.12947.

Mallo M, Ziveri P, Mortyn G, Schiebel R, Grelaud M. 2017. Low planktic foraminiferal diversity and abundance observed in a 2013 West-East Mediterranean Sea transect, Biogeosciences, 14, pp. 2245-2266.

Mohiuddin, M.M. et al. 2004. Seasonality of biogenic particle and planktonic foraminifera fluxes: Response to hydrographic variability in the Kuroshio Extension, northwestern Pacific Ocean. Deep-Sea Research Part I: Oceanographic Research Papers, 51(11), pp.1659-1683.

Mohiuddin, M.M., Nishimura, A. \& Tanaka, Y., 2002. Regional and interannual productivity of biogenic components and planktonic foraminiferal fluxes in the northwestern Paciçc Basin. Marine Micropaleontology, 45.

Mohiuddin, M.M., Nishimura, A. \& Tanaka, Y., 2005. Seasonal succession, vertical distribution, and dissolution of planktonic foraminifera along the Subarctic Front: Implications for paleoceanographic reconstruction in the northwestern Pacific. Marine Micropaleontology, 55(3-4), pp.129-156.

Morard, R. et al. 2013. Ecological modeling of the temperature dependence of cryptic species of planktonic Foraminifera in the Southern Hemisphere. Palaeogeography, Palaeoclimatology, Palaeoecology, 391, pp.13-33.

Olsen, A. et al. 2016. The global ocean data analysis project version 2 (GLODAPv2) - An internally consistent data product for the world ocean. Earth System Science Data, 8(2), pp.297-323. 
Pados, T. \& Spielhagen, R.F., 2014. Species distribution and depth habitat of recent planktic foraminifera in Fram Strait, Arctic Ocean. Polar Research, 33(Ehrenberg 1861).

Peterson, M.N., 1966. Calcite: rates of dissolution in a vertical profile in the central pacific. Science, 154(3756), pp.1542-1544.

Prell, W.L. \& Curry, W.B., 1981. Faunal and isotopic indices of monsoonal upwelling: Western Arabian Sea. Oceanologica Acta, 4, pp.91-98.

Roden, G.I., 1995. Aleutian Basin of the Bering Sea: Thermohaline, oxygen, nutrient, and current structure in July 1993. Journal of Geophysical Research, 100(C7), p.13539.

Ruddiman, W.F. \& Heezan, B.C., 1967. Differential solution of Planktonic Foraminifera. Deep Sea Research and Oceanographic Abstracts, 14(6), pp.801-802.

Rutherford, S., D'Hondt, S. \& Prell, W., 1999. Environmental controls on the geographic distribution of zooplankton diversity. Nature, 400(6746), pp.749-753.

Sadekov, A.Y. et al. 2016. Geochemical imprints of genotypic variants of Globigerina bulloides in the Arabian Sea. Paleoceanography, 31(10), pp.1440-1452.

Sautter, R, L. \& Thunell, R.C., 1989. Seasonal succession of planktonic foraminifera; results from a four-year time-series sediment trap experiment in the Northeast Pacific. Journal of Foraminiferal Research, 19(4), pp.253-267.

Schiebel, R. et al. 2001. Planktic foraminiferal production stimulated by chlorophyll redistribution and entrainment of nutrients. Deep-Sea Research Part I: Oceanographic Research Papers, 48(3), pp.721-740.

Schiebel, R., 2002. Planktic foraminiferal sedimentation and the marine calcite budget. Global Biogeochem. Cycles, 16(4), p.1065.

Schiebel, R. \& Hemleben, C., 2017. Planktic foraminifers in the modern ocean, Springer Berlin Heidelberg.

Siccha, M. \& Kucera, M., 2017. Data Descriptor : ForCenS , a curated database of planktonic foraminifera census counts in marine surface sediment samples. Scientific Data, 4, pp.1-12.

Stabeno, P.J. \& Reed, R.K., 1994. Circulation in the Bering Sea Basin Observed by Satellite-Tracked Drifters: 1986-1993. Journal of Physical Oceanography, 24(4), pp.848-854.

Thiede, J., 1975. Distribution of foraminifera in surface waters of a coastal upwelling area. Nature, 253(5494), pp.712-714.

Thunell, R. \& Honjo, S., 1987. Seasonal and interannual changes in planktonic foraminiferal production in the North Pacific. Nature, 328, pp.335-337.

Thunell, R.C. \& Sautter, R, L., 1991. Planktonic foraminiferal response to upwelling and seasonal hydrographic conditions; sediment trap results from San Pedro Basin, Southern California Bight. Journal of Foraminiferal Research, 21, pp.347-363.

Tolderlund, D.S. \& Bé, A.W.H., 1971. Seasonal distribution of planktonic foraminifera in the western North Atlantic. Micropaleontology, 17(3), pp. 297-329.

Wyrtki, K., 1981. An Estimate of Equatorial Upwelling in the Pacific. Journal of Physical Oceanography, 11(9), pp.1205-1214.

Yan, X. et al. 1992. Temperature and Size Variabilities of the Western Pacific Warm Pool. Science. 258 (5088), pp.1643-1645. 
Yasuda, I., 2003. Hydrographic structure and variability in the Kuroshio- Oyashio transition area. Journal of Oceanography, 59, pp.389-402.

Žarić, S. et al. 2005. Sensitivity of planktic foraminifera to sea surface temperature and export production as derived from sediment trap data. Marine Micropaleontology, 55(1-2), pp.75105.

Zweng, M.M. et al. 2013. World Ocean Atlas 2013, Volume 2: Salinity. NOAA Atlas NESDIS, 2(1), p.39. 


\section{Tables}

\begin{tabular}{|c|c|c|c|c|c|}
\hline Station No. & $\begin{array}{c}\text { Lat } \\
(\mathrm{dec})\end{array}$ & $\begin{array}{l}\text { Long } \\
(\mathrm{dec})\end{array}$ & Date & Depth (m) & Area \\
\hline \multicolumn{6}{|l|}{ Multinet } \\
\hline $\mathrm{SO} 202-05-02$ & 46.97 & 156.98 & $12 / 07 / 2009$ & $0-1000$ & off Kurile-Kamchatka Trench \\
\hline SO202-04-10 & 52.74 & 179.85 & $20 / 07 / 2009$ & $0-1000$ & southern Bowers Ridge \\
\hline $\mathrm{SO} 202-03-13$ & 54.98 & 177.96 & $22 / 07 / 2009$ & $0-1000$ & northern Bowers Ridge \\
\hline SO202-04-14 & 56.79 & 178.82 & $22 / 07 / 2009$ & $0-1000$ & central Aleutian Basin \\
\hline SO202-04-15 & 59.51 & -179.85 & $24 / 07 / 2009$ & $0-1000$ & N-bering Slope Pervenets/ Navarin Canyons \\
\hline SO202-04-27 & 54.30 & -149.60 & $02 / 08 / 2009$ & $0-1000$ & Patton Seamount \\
\hline SO202-02-31 & 49.68 & -152.55 & $05 / 08 / 2009$ & $0-1000$ & Seamount East SAP \\
\hline SO202-05-33 & 45.08 & -174.14 & $10 / 08 / 2009$ & $0-1000$ & North of Chinook Trough \\
\hline SO202-05-34 & 40.89 & -177.68 & $12 / 08 / 2009$ & $0-1000$ & East of southern Emperor Trough \\
\hline \multicolumn{6}{|l|}{ Multicore } \\
\hline SO202-02-06 & 51.90 & 166.49 & $16 / 07 / 2009$ & 3422 & Obruchev Rise \\
\hline SO202-02-07 & 51.27 & 167.70 & $16-17 / 07 / 2009$ & 2349 & Detroit Seamount \\
\hline SO202-04-13 & 54.98 & 177.96 & $22 / 07 / 2009$ & 1383 & northern Bowers Ridge \\
\hline SO202-01-27 & 54.30 & -149.60 & $02 / 08 / 2009$ & 2916 & Patton Seamounts \\
\hline SO202-05-31 & 49.68 & -152.55 & $05 / 08 / 2009$ & 3744 & Seamount East SAP \\
\hline SO202-02-40 & 38.41 & 160.34 & $18 / 08 / 2009$ & 3462 & N Shatsky Rise \\
\hline \multicolumn{6}{|c|}{ CDISK-IV Plankton nets } \\
\hline KM1712-St.1 & 22.75 & -157.98 & $03 / 08 / 2017$ & $0-300$ & Station ALOHA \\
\hline KM1712-St.2 & 27.74 & -155.25 & $06 / 08 / 2017$ & $0-300$ & Subtropical gyre \\
\hline KM1712-St.3 & 35.27 & -151.00 & $13 / 08 / 2017$ & $0-250$ & Transition zone \\
\hline KM1712-St.4 & 41.76 & -148.26 & $17 / 08 / 2017$ & $0-200$ & Transition zone \\
\hline KM1712-St.5 & 49.82 & -149.22 & $24 / 08 / 2017$ & $0-150$ & Subpolar gyre \\
\hline Sediment Traps & & & & & Reference \\
\hline $50 \mathrm{~N}$ & 50.00 & 165.00 & $1997-2001$ & 3260 & Kuroyanagi et al.,2008 \\
\hline $40 \mathrm{~N}$ & 40.00 & 165.00 & $1997-2000$ & 2986 & Kuroyanagi et al.,2008 \\
\hline Papa & 50.10 & -144.90 & $1982-1986$ & 3858 & Sautter and Thunell, 1989 \\
\hline $\mathrm{AB}$ & 53.50 & 176.90 & 1990-1999 & 3198 & Asahi and Takahashi, 2007 \\
\hline SA & 49.00 & 174.00 & 1990-1999 & 4812 & Asahi and Takahashi, 2007 \\
\hline
\end{tabular}

Table 1: Key station information for sites in this study alongside station information for compiled sediment trap data. Note that numbers in bold refer to station numbers used in Figure 1. CTD data was also collected for all of the multinet sites. Station information for the core-top compilation can be found within the supplementary information. 


\section{Figures}

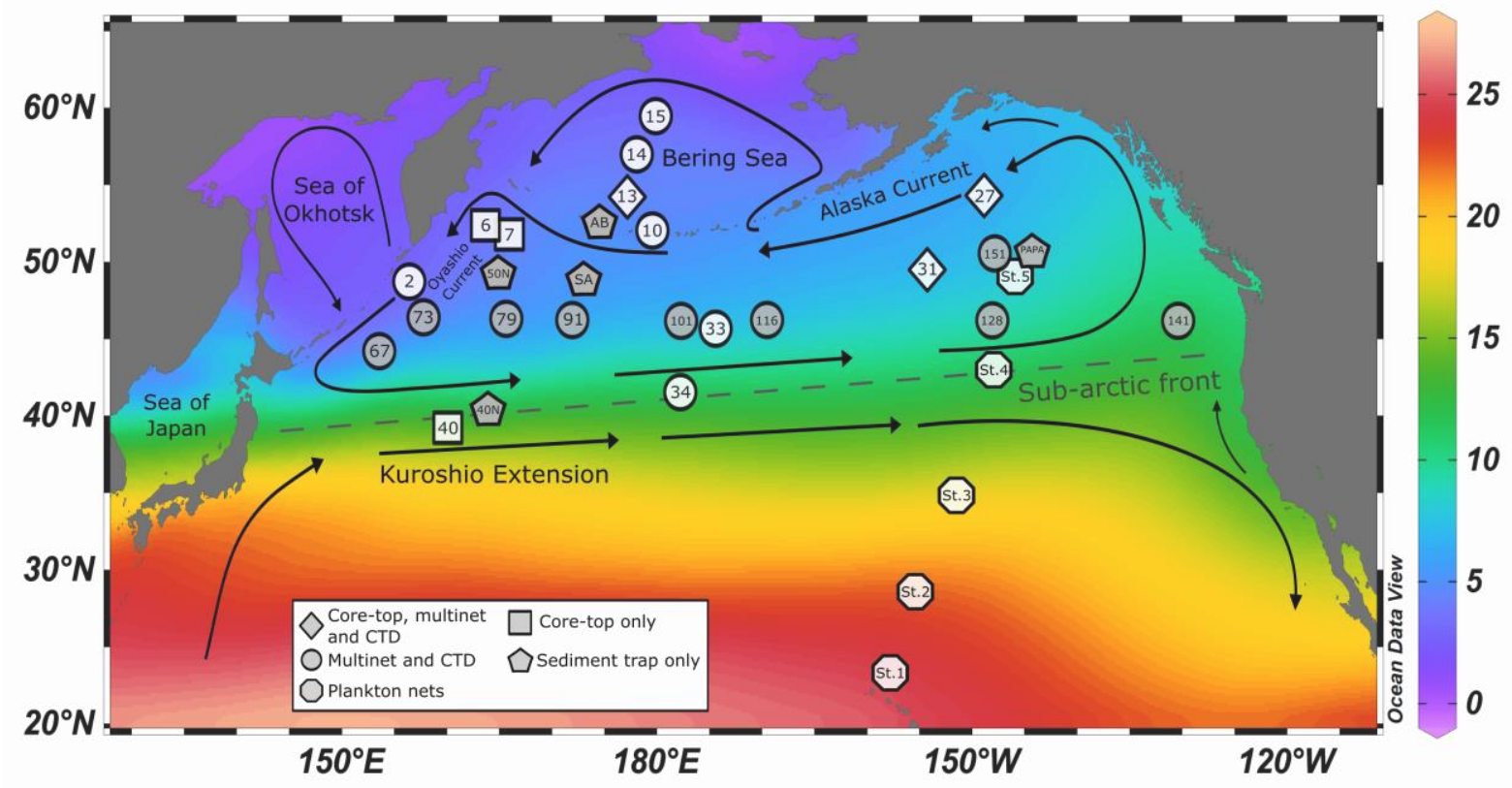

Figure 1: Hydrographic map showing the major current systems in the North Pacific and the sites used in this study. Arrows represent the direction of the major current systems in the North Pacific based on Gersonde (2012) and background colours represent mean annual temperature from 1955-2012 in degrees Celsius based on data from the world ocean atlas 2013 (Locarini et al. 2013). Diamonds show sites where core-top and multinet material was available; circles show sites where only multinet material was available; octagons show plankton net sites; squares show sites where only core-top material was available; pentagons show sites where sediment trap data was compiled. White shapes indicate new sites presented in this study, whilst grey shapes indicate sites where data was compiled from previous studies (Sautter and Thunell, 1989; Takahashi et al. 2000; Asahi and Takahashi, 2007; Kuroyanagi et al. 2008). Numbers here refer to the numbers in station numbers in bold listed in Table 1. 


\section{Multinet assemblages}

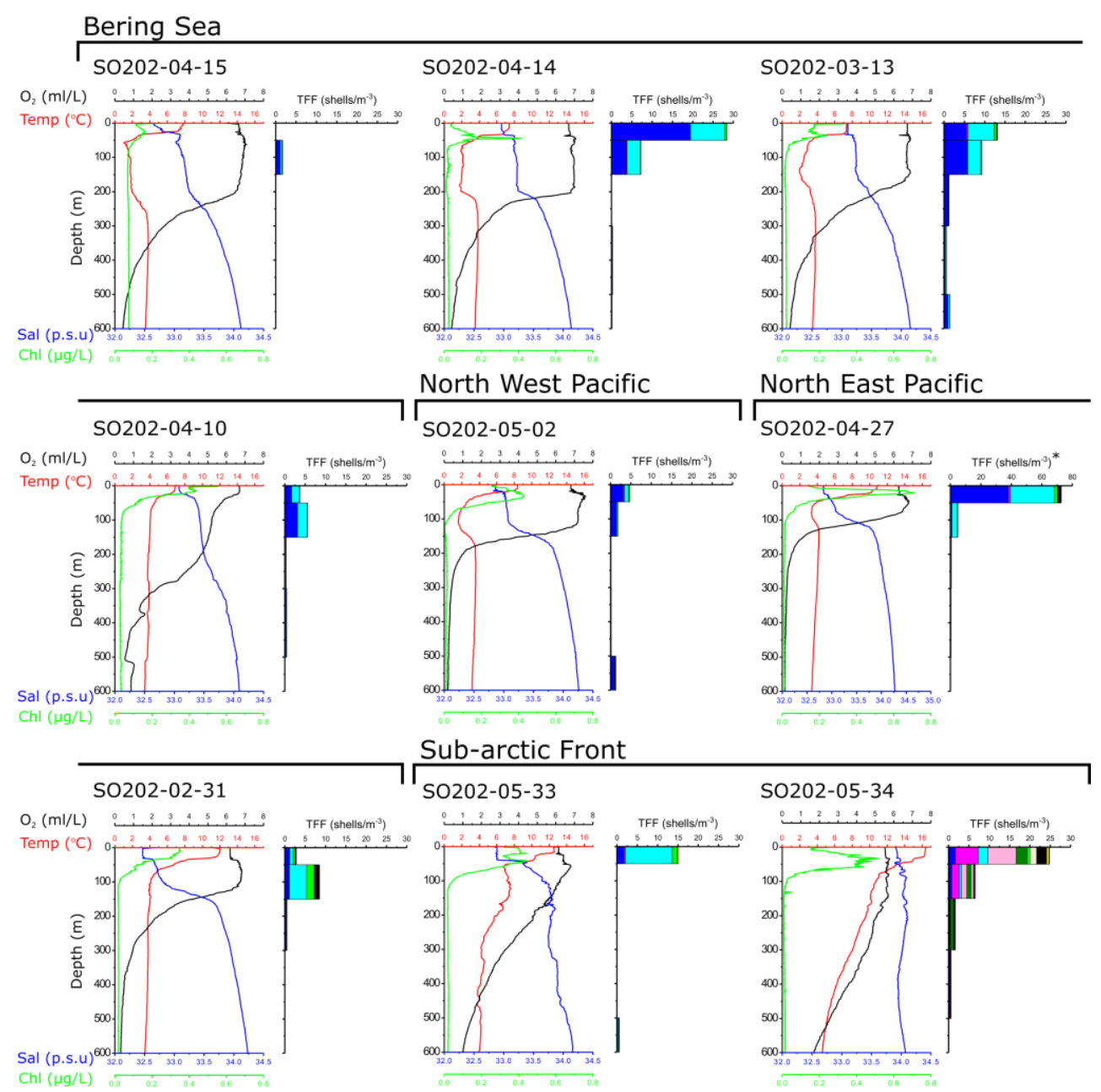

\section{Core-top assemblages}

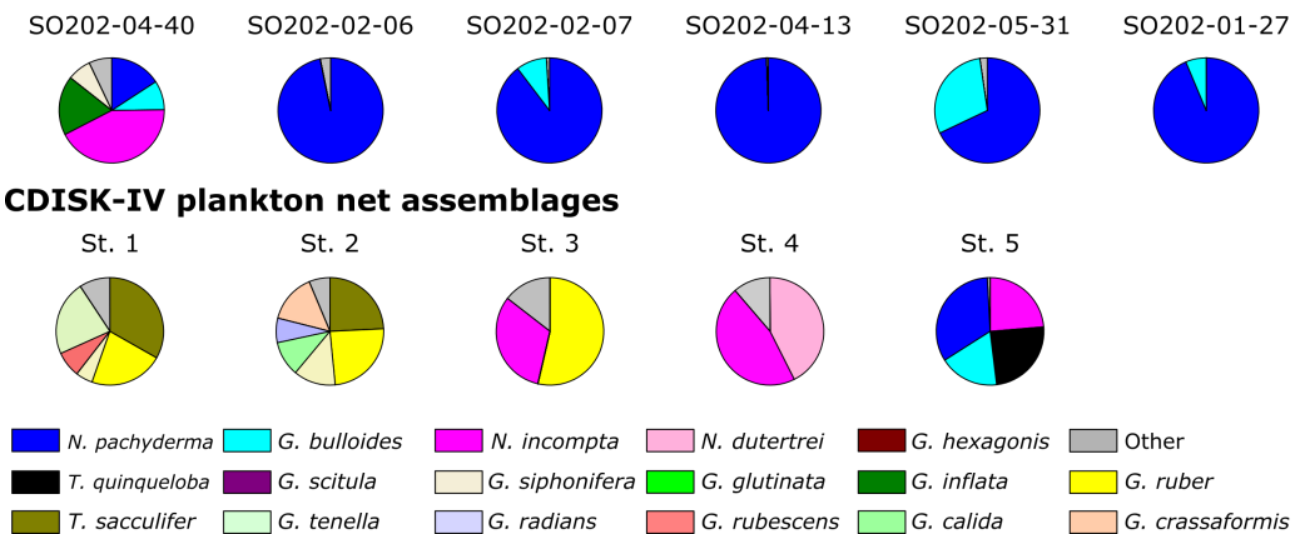

Figure 2: Vertical profiles down to $600 \mathrm{~m}$ of total foraminifera flux (TFF) and CTD data from 9 new sites in the North Pacific. CTD data comprises of four variables: temperature (red line) in ${ }^{\circ} \mathrm{C}$; oxygen concentration (black line) in $\mathrm{ml} / \mathrm{L}$; salinity (dark blue line) in p.s.u. and chlorophyll concentration (green line) in $\mu \mathrm{g} / \mathrm{L}$ which was calculated using florescence data. TFF is given in shells $/ \mathrm{m}^{-3}$ where different coloured bars represent different planktic foraminifera species, as denoted in the key. TFF is presented for five multinet depth intervals: 0-50 m; 50-150 m; 150-300 m; 300-500 m and 500-1000 m. Pie charts denoting core-top assemblages for 6 new sites in the subpolar North Pacific are displayed from East to West with accurate locations displayed in figure 1. Pie charts denoting plankton net assemblages for 5 new sites are displayed from South to North with accurate locations displayed in figure 1. *note different TFF scale due to very high abundance of foraminifera at this site SO202-04-27. 


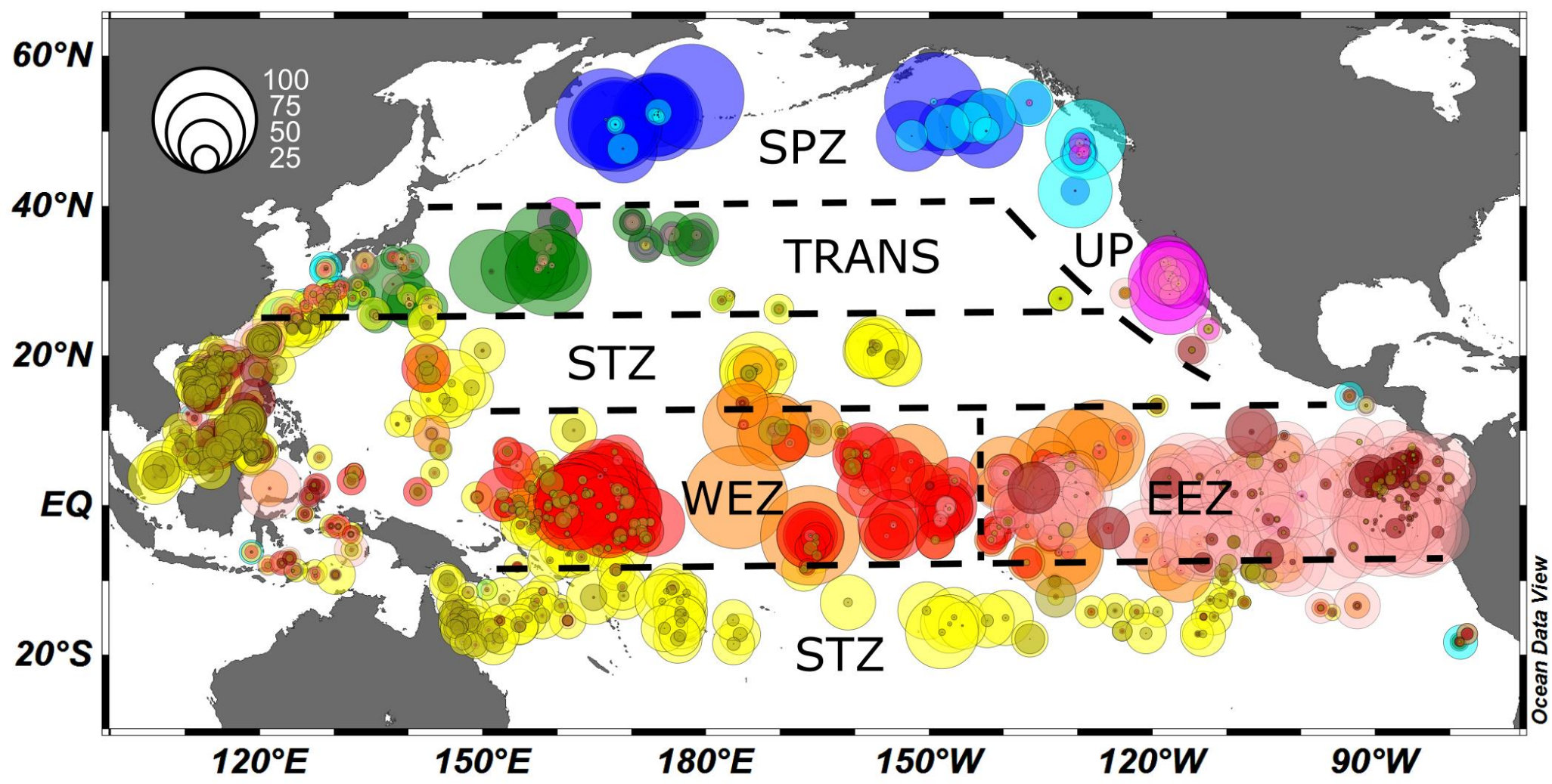

\begin{tabular}{|c|c|c|c|c|}
\hline N. incompta & G. bulloides & N.dutertrei & G.inflata & G.menardii \\
\hline N. pachyderma & G. ruber & P.obliquiloculata & G. tumida & T. sacculifer \\
\hline
\end{tabular}

Figure 3: Distribution and abundance of North Pacific planktic foraminifera based on new subpolar North Pacific sites and compiled data from Coulbourn et al. 1980 and Kurcera et al. 2005 . Size of bubbles represent percentage abundance of planktic foraminifera and colour represents different species of planktic foraminifera, as denoted by the key. Six faunal zones are described based on the distribution of 10 major species of planktic foraminifera: SPZ is the subpolar zone; TRANS is the transitional zone; UP is the upwelling zone; STZ is the subtropical zone; WEZ is the west equatorial zone; EEZ is the east equatorial zone. 


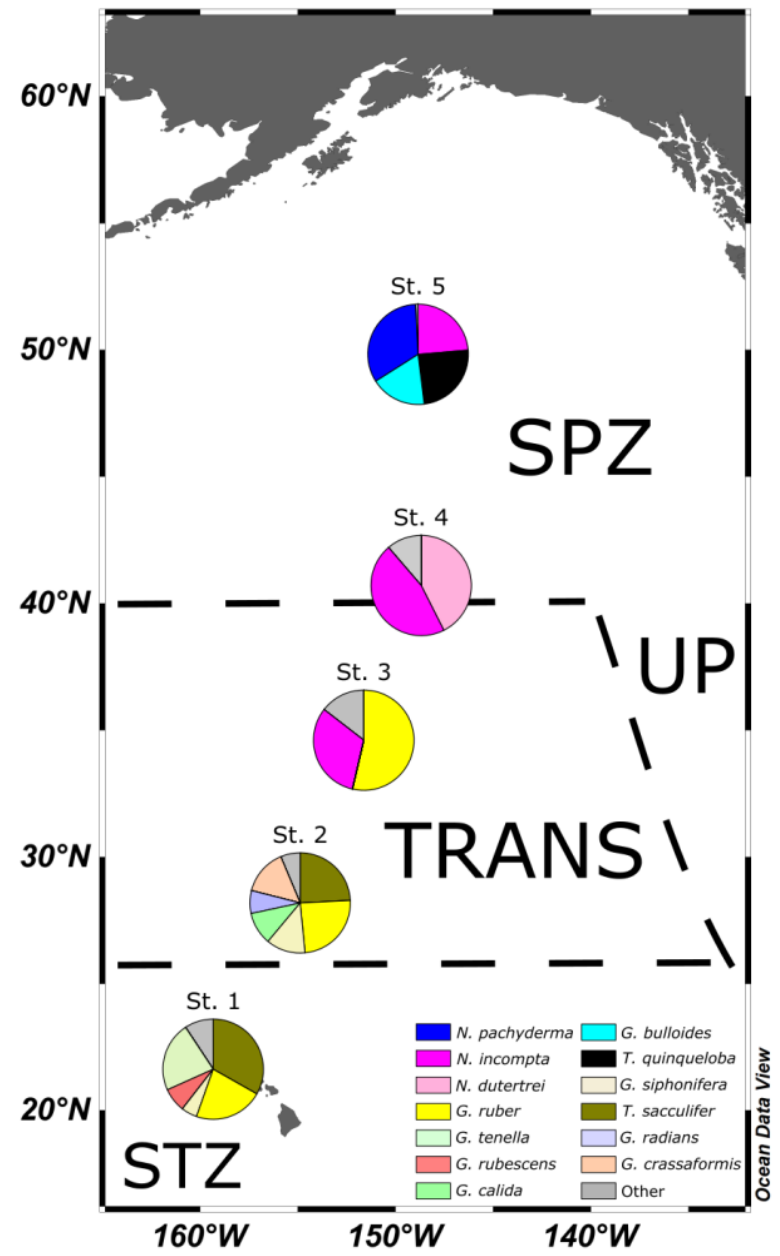

Figure 4: Pie charts showing new assemblage data from 5 plankton nets taken during the CDISK-IV KM1712 cruise. The map is overlain with faunal zones depicted in figure 3 indicating the validity of the zones within surface water samples. SPZ is the Sub-Polar Zone; UP is the Upwelling Zone; TRANS is the Transitional Zone; STZ is the Sub-Tropical Zone. 

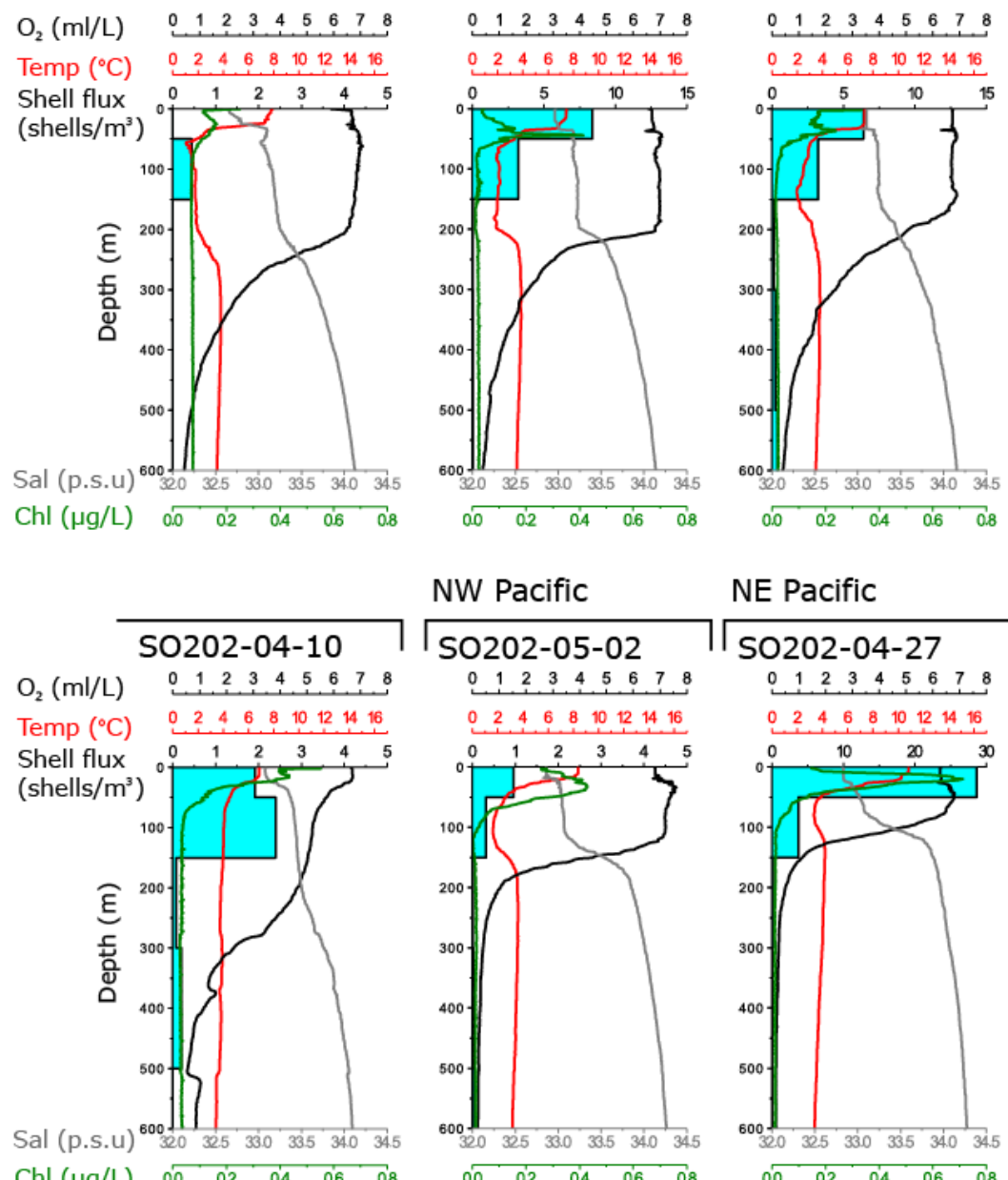

NW Pacific

NE Pacific

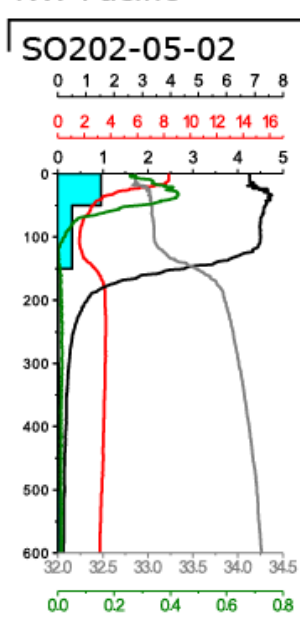

\section{SO202-04-27}

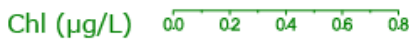

Sub-arctic Front
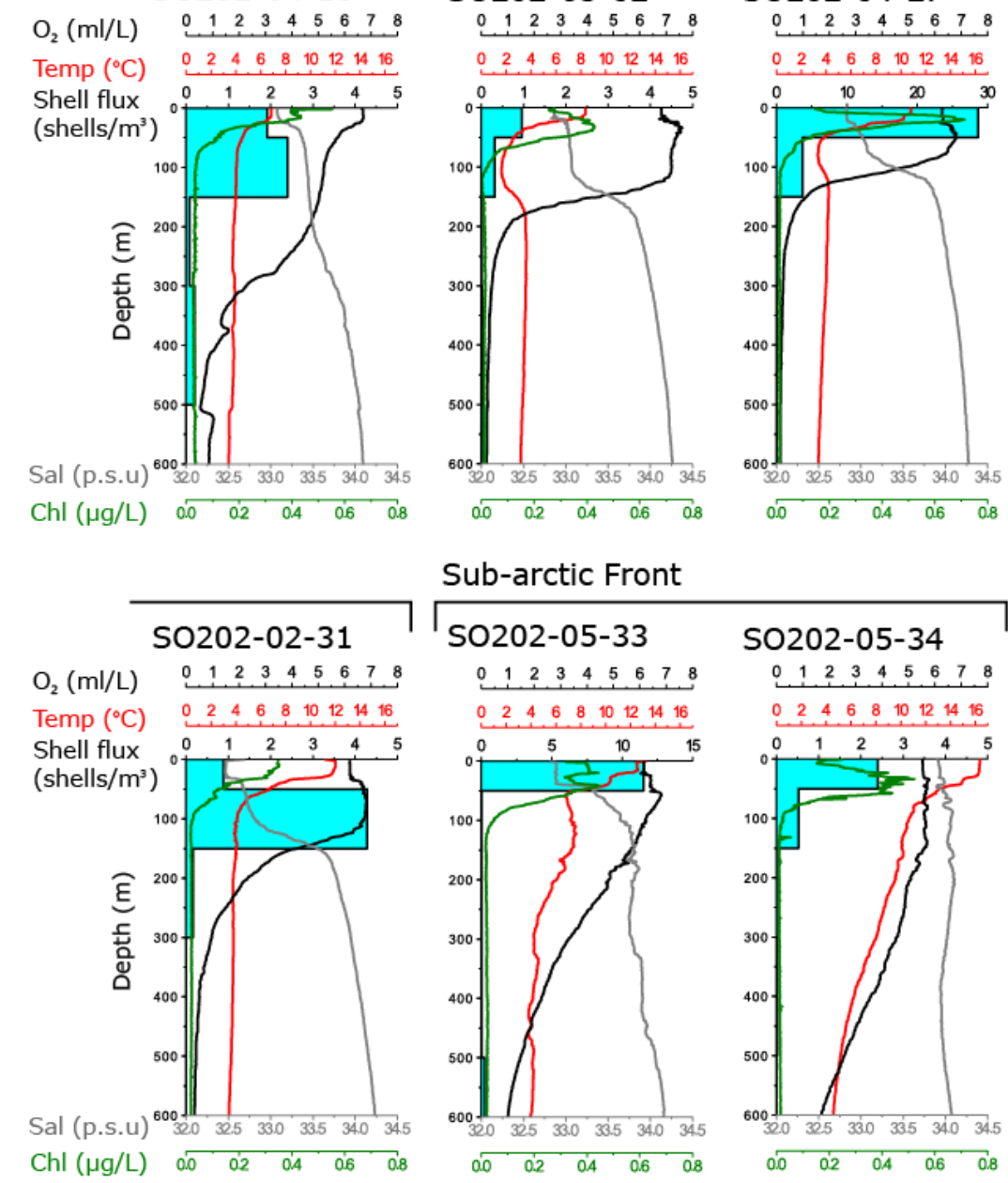

Figure 5: Vertical profile of $G$. bulloides flux and CTD data to $600 \mathrm{~m}$ from 9 new sites in the North Pacific. G. bulloides flux is shown at 5 depth intervals: 0-50 m; 50-150 m; 150-300 m; 300-500 m; 500-1000 m. CTD data include: oxygen concentration (black line) in $\mathrm{ml} / \mathrm{L}$; temperature (red line) in ${ }^{\circ} \mathrm{C}$; salinity (grey line) in p.s.u; chlorophyll concentration (green line) in $\mu \mathrm{g} / \mathrm{L}$, derived from fluorescence data. Light blue bars indicate the shell flux (shells $/ \mathrm{m}^{3}$ ) of G. bulloides, note variable shell flux scales depending on site. 

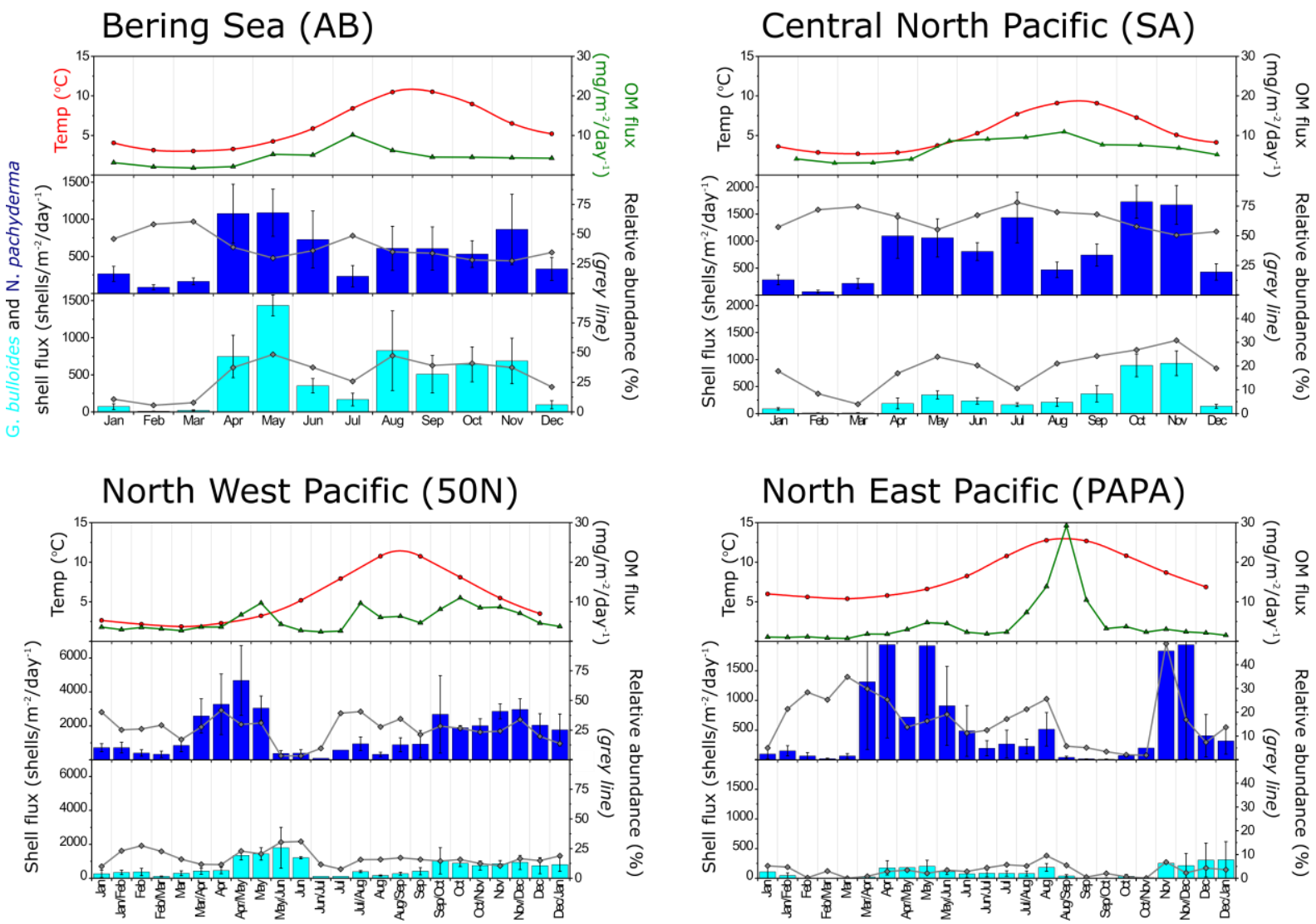

North West Pacific (40N)

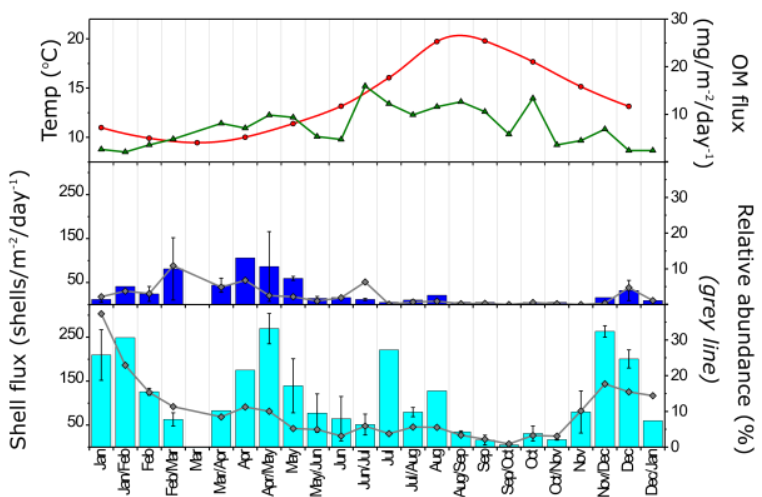

Figure 6: Compiled sediment trap and hydrological data from five sites in the North Pacific. All sites contain monthly or bi-weekly data on shell flux (shells $/ \mathrm{m}^{-2} / \mathrm{day}^{-1}$ ) of $\mathrm{N}$. pachyderma (dark blue bars) and G. bulloides (light blue bars) as well as the relative abundance (\%) of each species in the assemblage. Where multiple years of sediment trap data was available from the same site, the data was averaged with error bars defining the standard error. Organic matter flux $\left(\mathrm{mg} / \mathrm{m}^{-2} / \mathrm{day}^{-1}\right)$ was also compiled for each sediment trap (green line). Monthly temperature was derived for each site using ocean data view's 3D estimation tool and the world ocean atlas 2013 monthly datasets (red line). Sediment trap data for each site was compiled from the following publications: Site AB (Bering Sea) and SA (central Pacific) (19901999) from Takahashi et al. 2000, Asahi and Takahashi, 2007; Sites 40N (1997-2000) and 50N (1997-2001) (North West Pacific) from Kuroyanagi et al. 2008; Station PAPA (1982-1986) from Sautter and Thunell, 1989. 
10
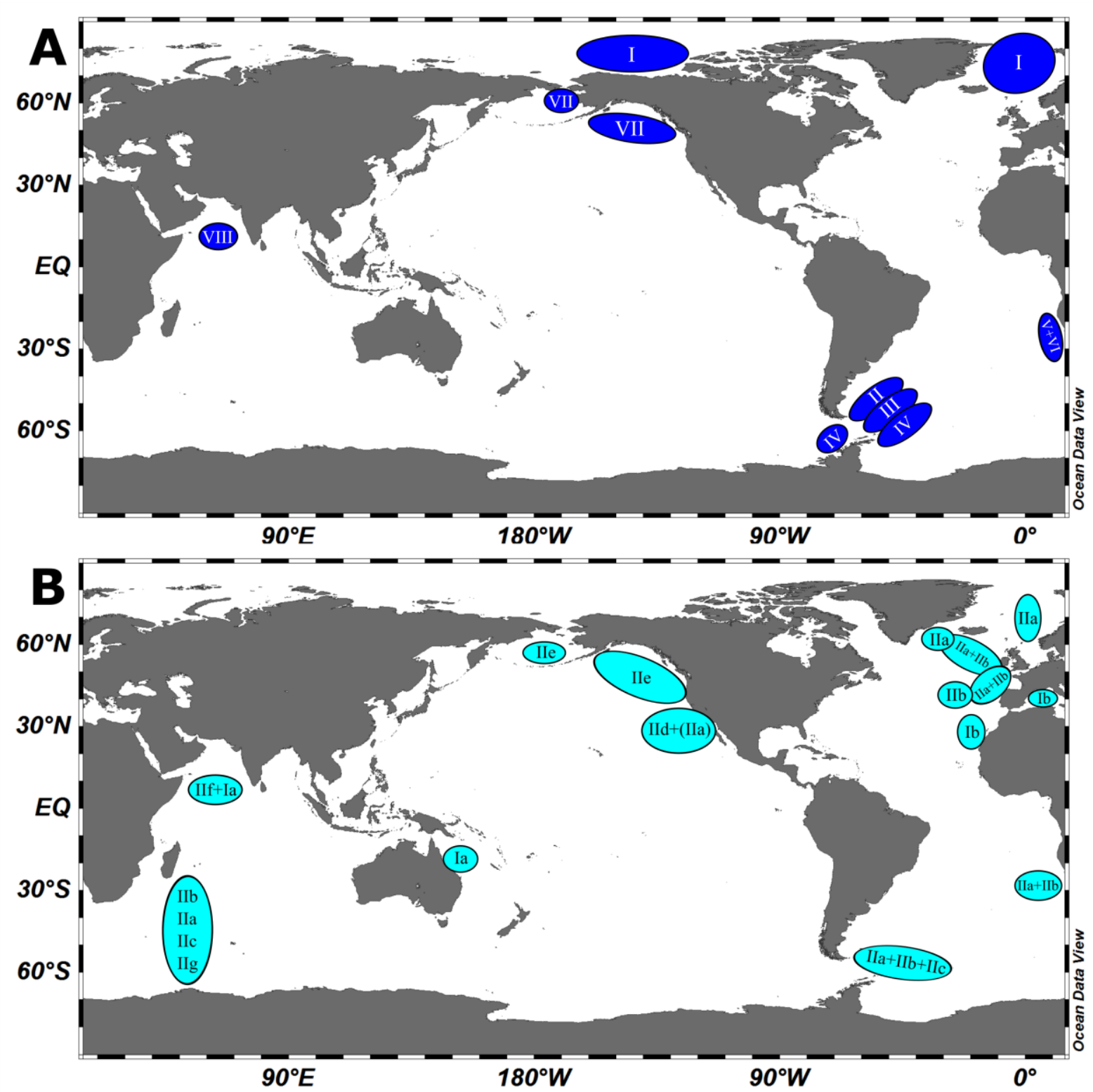

Figure 7: Map showing global distribution of genotypes of two species of planktic foraminifera (A) N. pachyderma and (B) G. bulloides based on Darling et al. 2008 and Morard et al. 2013. 

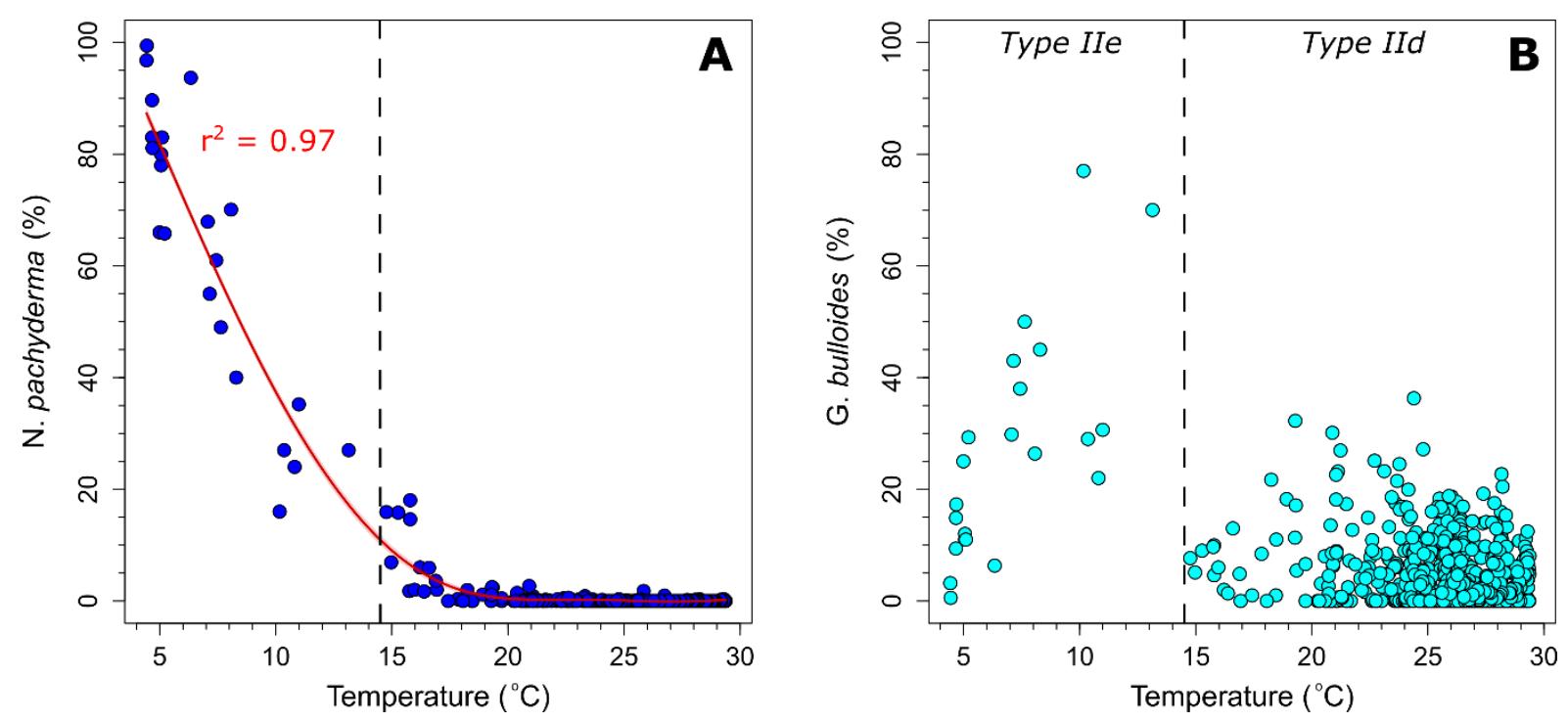

Figure 8: Scatter plot of planktic foraminifera species against sea surface temperature (SST). (A) Percentage abundance of $N$. pachyderma from new core-top compilation plotted against SSTs from world ocean atlas 2013 (Locarnini et al. 2013) derived using Ocean Data View's 3D estimation tool. We used a generalized additive model (GAM) from the 'mgcv' package in R to determine the relationship shown by the red line in A. (B) Percentage abundance of G. bulloides from core-top new compilation plotted against SSTs from the world ocean atlas 2013 (Locarnini et al. 2013) derived using Ocean Data View's 3D estimation tool. Two populations of $G$. bulloides can extracted from the plot: a low temperature population, likely comprising of genotype lle and a high temperature population, likely comprising of genotypes Ila and Ild (based on cryptic species distribution work by Darling et al. 2008). 
s0202-04-15

$\mathrm{O}_{2}(\mathrm{ml} / \mathrm{L})$

Temp $\left({ }^{\circ} \mathrm{C}\right)$

Shell flux

(shells $/ \mathrm{m}^{3}$ )
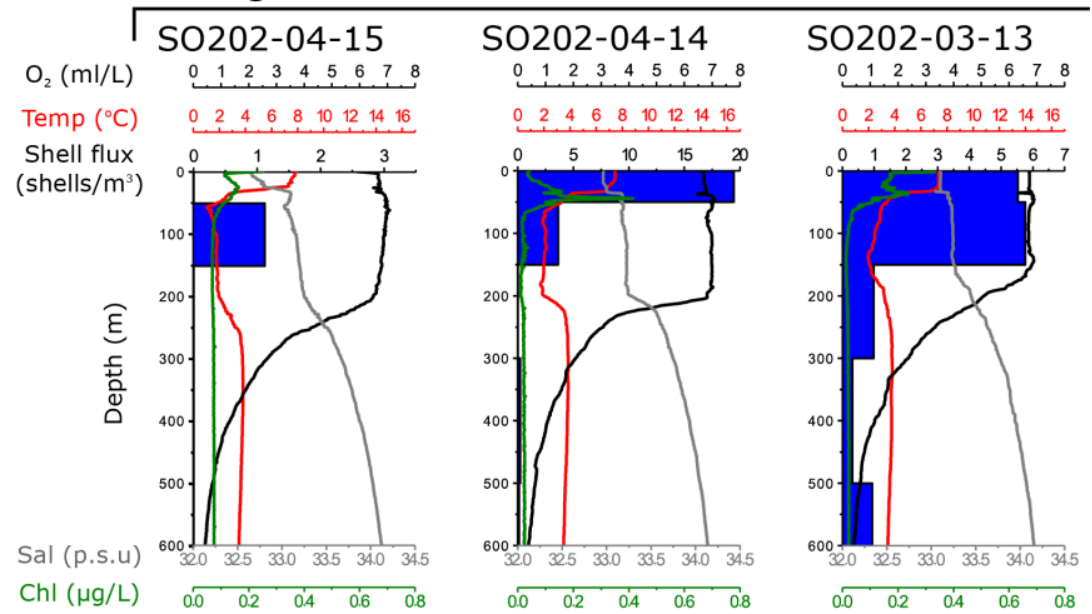

42

43

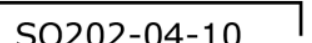

NW Pacific

Temp $\left({ }^{\circ} \mathrm{C}\right)$

Shell flux
$\left(\right.$ shells $\left./ \mathrm{m}^{3}\right)$
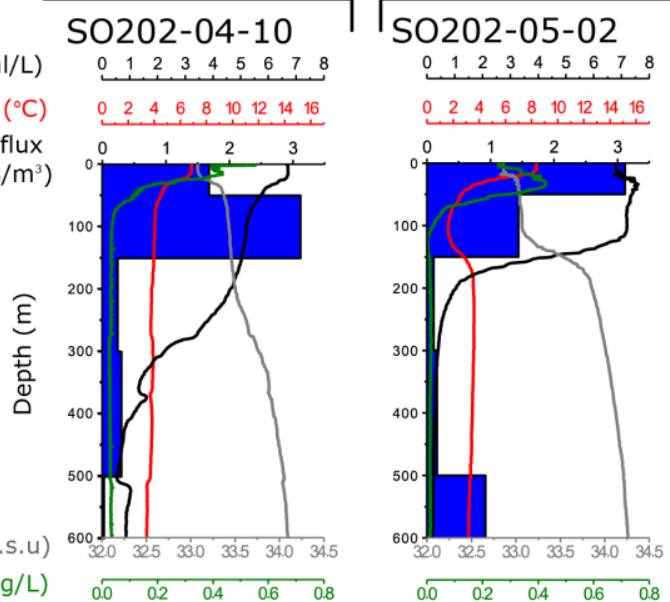

\section{NE Pacific}
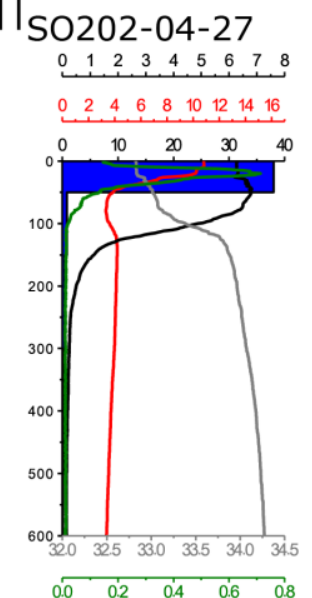

$\mathrm{O}_{2}(\mathrm{ml} / \mathrm{L})$

$$
\text { SO202-02-31 }
$$

Sub-arctic Front

$$
\text { Shell flux }
$$
(shells $/ \mathrm{m}^{3}$ )
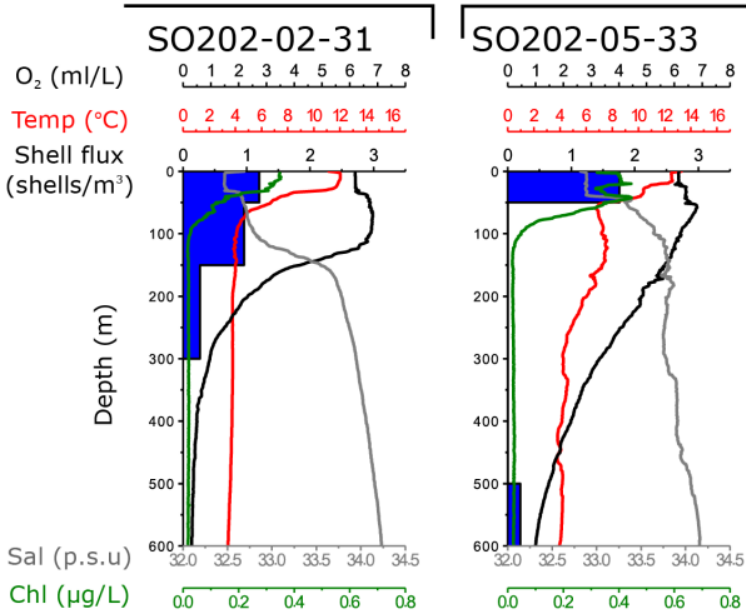

\section{SO202-05-34}

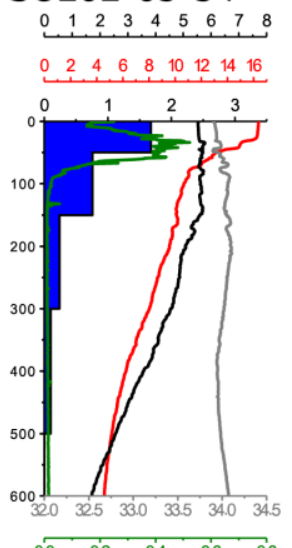

Figure 9: Vertical profile of $N$. pachyderma and CTD data to $600 \mathrm{~m}$ from 9 new sites in the North Pacific. CTD data include: oxygen concentration (black line) in $\mathrm{ml} / \mathrm{L}$; temperature (red line) in ${ }^{\circ} \mathrm{C}$; salinity (grey line) in p.s.u; chlorophyll concentration (green line) in $\mu \mathrm{g} / \mathrm{L}$, derived from fluorescence data. Dark blue bars indicate the shell flux (shells $/ \mathrm{m}^{3}$ ) of $N$. pachyderma, note variable shell flux scales depending on site. 

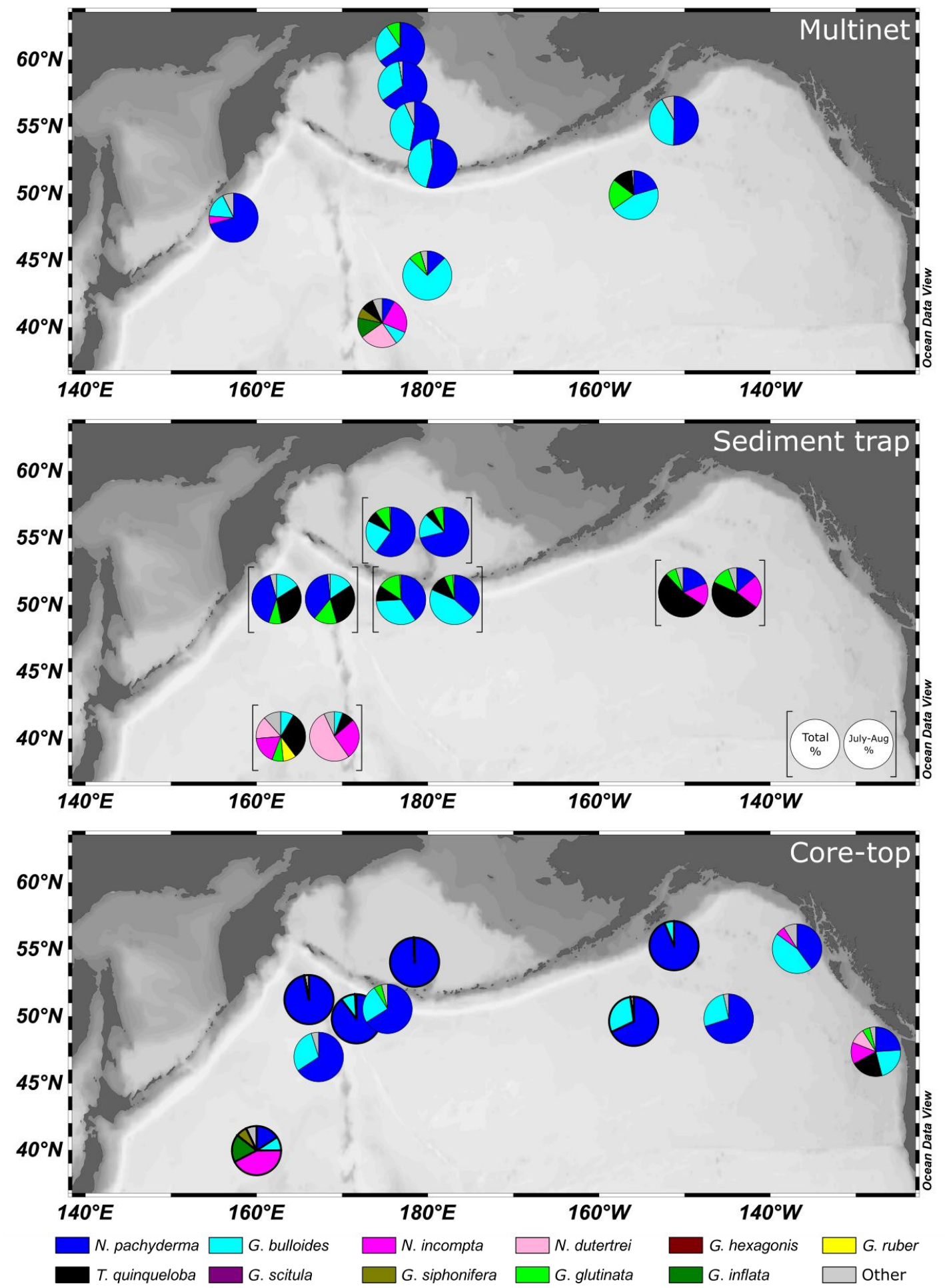

Figure 10: Bathymetric maps with pie charts comparing percentage abundance of planktic foraminifera in new multinets, compiled sediment trap data and core-top data from the same or adjacent sites in the North Pacific. Multinet pie charts show the average relative abundance for 0-500 $\mathrm{m}$ in the water column taken in July and August. Sediment trap data shows the average abundance over the course of the sediment trap (total \%) adjacent to the average abundance during only July and August (July-Aug \%). The similarity between the two sets of sediment trap data suggest little influence of seasonality on our multinets. Core-top data includes new data from our sites (bold pie charts) and data from adjacent sites taken from our core-top compilation. Note the reduction in diversity exhibited in subpolar North Pacific sites and the bias of preservation towards N. pachyderma over G. bulloides when comparing multinets to core-tops. 


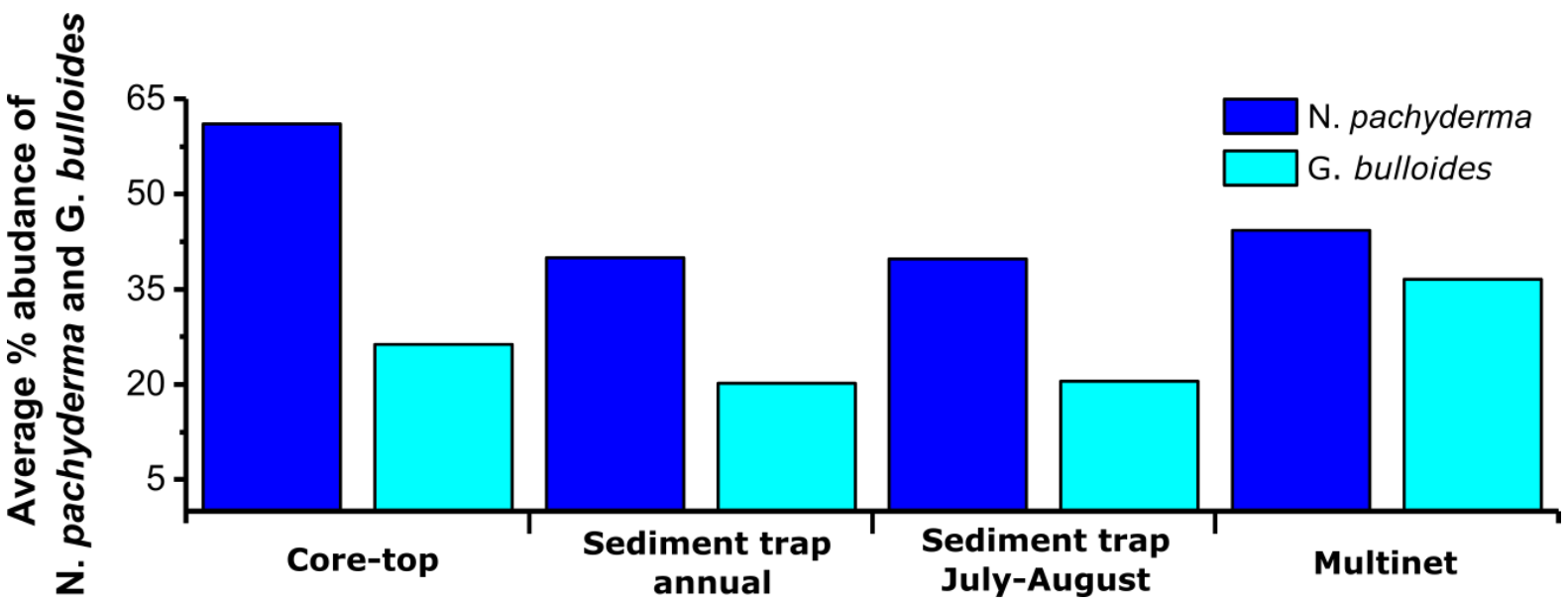

Figure 11: Average percentage abundance of N. pachyderma and G. bulloides compared between Core-top, sediment trap and multinet data. Relative abundances of N. pachyderma (dark blue bar) and G. bulloides (light blue bar) were averaged for all sites seen in Figure 10. This figure highlights the lack of difference between July-August sediment trap and annual sediment trap abundances compared to a larger difference between Core-top and multinet abundance of G. bulloides. This suggests the cause of these discrepancies is likely due to sediment dissolution rather than seasonality. 